Journal of Global Economic Analysis, Volume 2 (2017), No. 1, pp. 120-165.

\title{
A Proximity-Based Approach to Labor Mobility in CGE Models with an Application to Sub-Saharan Africa
}

\author{
BY HANS LOFGRENa AND MARTÍN CICOWIEZ ${ }^{\mathrm{b}}$
}

The ease with which workers can move between sectors has a strong impact on how shocks affect an economy. This paper introduces an approach to labor mobility with frictions. Under the approach, worker capabilities (their efficiencies in different sectors) depend on their sector affiliation. If workers belonging to sector a move to $a^{\prime}$, their efficiency shortfall compared to workers assigned to $a^{\prime}$ is measured by a proximity parameter, $0 \leq$ prox $_{a, a^{\prime}} \leq 1$. If prox $x_{a, a^{\prime}}<1$, the efficient quantity reaching $a^{\prime}$ is below the physical quantity. In this setting, profit-maximizing producers, facing given physical worker wages (which may vary depending on sectoral affiliation), pay the same wage per efficiency unit irrespective of origin and thus pay less efficient workers a lower wage per physical unit. This approach to labor mobility is tested in a static CGE model that is applied to an illustrative sub-Saharan African dataset with sector proximities defined using the approach of the product-space literature. Simulations of positive export price shocks show that, the higher the proximities, the stronger the labor reallocation and the welfare gains.

JEL codes: C68, J31, O24

Keywords: Computable General Equilibrium Models; Labor Mobility; Factor Mobility; Wage Differentials; Development Planning and Policy.

\section{Introduction}

The movement of labor between sectors is a core aspect of structural change in economies throughout the world. ${ }^{1}$ The effects of changes in prices, technology, and

a World Bank, 1818 H St. NW, Washington, DC 20433, USA (e-mail: hlofgren@worldbank.org).

b Center for Distributive, Labor and Social Studies (CEDLAS), University Nacional de La Plata, Calle 6 \#777, La Plata, 1900, Argentina (e-mail: martin@depeco.econo.unlp.edu.ar).

1 We use the two terms "sector" and "activity" interchangeably with the same definition as "industry" in the System of National Accounts, i.e. a grouping of establishments (or producers) engaged in the same or similar kinds of activities classified in the same International Standard Industrial Classification of All Economic Activities (ISIC) code (United Nations 2003, p. 74). 
policies on production, trade and living standards are strongly influenced by the extent to which labor is able to relocate. In a literature survey, Hertel and Reimer (2005, p. 400) find that "the poverty impacts of trade reform often hinge crucially on how well the increased demand for labour in one part of the economy is transmitted to the rest of the economy." Drawing on a global CGE analysis, van der Mensbrugghe (2007) indicates that the treatment of labor market segmentation and sectoral wage differences has a strong impact on simulated welfare impacts of the Doha round of trade reform, especially for developing countries. The findings reported in Porto and Hoekman (2010) indicate that labor market frictions in developing countries are substantial, giving rise to costly labor market adjustments and limiting labor reallocation. Similarly, even though the analysis has typically been done from a firm (as opposed to sector) perspective, labor adjustments costs are a major focus in the labor economics literature (for example, see Hamermesh 1989, Cooper and Willis 2009, and Cooper et al. 2015).

The Computable General Equilibrium (CGE) literature includes a variety of approaches to mobility, the most common being to assume that mobility between any pair of sectors is either impossible or unconstrained. In this paper, we present and test an innovative approach that, in contrast with this dichotomy, views intersectoral labor mobility as falling along a continuum. It offers a means of making sure that simulations with CGE models more closely approximate empirical patterns for labor movements and/or wage differences between workers of different origins (including incumbent workers) that are employed in a sector. The approach is inspired by the classic transportation model of the linear programming literature (for references, see Gass and Assad 2005, pp. 51-52) and the product-space (PS) literature due to Hausmann and coauthors (Hausmann and Klinger 2006; Hausmann et al. 2011).

The essence of our approach is that workers are viewed as having capabilities that to varying degrees permit them to be efficient in different sectors. As a consequence, reallocation of workers between sectors comes at a cost in the form of lost efficiency: labor that comes from another sector is less efficient than the labor that already works in the receiving sector. These efficiency losses are related to proximity between pairs of sectors, a key concept in the PS literature. It is valued between 0 and 1 and here used to measure the degree to which a worker in the sector of origin possesses the capabilities that are required in the sector of destination. In the PS literature, proximity is defined on the basis of revealed comparative advantage (RCA). We also draw on RCA-related data in the illustrative application in this paper even though we do not consider this approach as ideal and, in the conclusions, discuss other options for future research. ${ }^{2}$

2 Strict adherence to the PS approach to the calculation of proximities would have the drawback of excluding values that differ across labor types (since PS proximities are single- 
The efficiency losses due to reallocation are related to a distinction between labor quantities in physical and efficiency units. For labor that stays within its sector of origin (or moves to a sector considered to be in the same location as it requires the same worker capabilities), physical and efficient labor quantities are identical and the proximity is equal to 1 . If labor moves to a different location (i.e., its proximity is less than 1), the efficient labor quantity received in the sector of destination falls short of the efficient (and physical) quantity of labor that departs from the sector of origin - the lower the proximity, the larger this shortfall. Profitmaximizing producers consider the gap between efficient and physical labor in their hiring decisions. They equalize payments to labor measured in efficiency units, as a result being willing to pay a higher wage (per physical unit) for a worker who already is in the sector, due to his/her higher degree of efficiency compared to a worker from a different location. This treatment of wages echoes the writings of Alfred Marshall, who coined and used the efficiency wage term to refer to wages that reflect the exertion of ability and efficiency in work. He argued that competition tends to equalize efficiency wages as opposed to the wages per time unit, which differ across workers with different levels of efficiency (Marshall 1920, Book VI, Chapter III); this is the same outcome that prevails at equilibrium in our labor mobility model. ${ }^{3}$

Given that proximities between sectors fall along a continuum, labor segmentation also appears along a continuum as opposed to the common dichotomy of treating labor in different sectors as belonging either to the same segment or to different, separate segments. However, the two extremes of this common dichotomy can still be captured as the special cases with all sectors having proximities of 1 or very low proximities for the cases of belonging to the same and fully separate segments, respectively. In the latter case, migration would not take place due to the fact that the (efficiency-based) wage offered in the destination sector would fall short of the wage in the sector of origin. In other respects, our approach is consistent with alternative, common treatments of other (non-mobility) aspects of labor market functioning, including the determination of total employment for each labor type (with or without unemployment or labor/leisure decisions), and the treatment of substitutability between labor categories within sectors.

A sector-based labor classification is natural given our focus on developing an approach that is applicable to multi-sector CGE models. However, data permitting, it would be both easy and often desirable to extend the labor

dimensional, defined by sector) or are asymmetric (since the PS proximity or distance from activity $a$ to activity $a^{\prime}$ is the same as the one from $a^{\prime}$ to $a$ ).

3 This usage deviates from that of modern efficiency-wage theories with links between wages and worker productivity, which may give raise to wage setting above market equilibrium. For a survey, see Weiss (1991). 
classification in the model to additional dimensions, such as educational attainment or achievement or what may be labeled as skill or occupation. If so, proximities would be defined in terms of the different dimensions taken together. To exemplify, if the two dimensions are sector and skill, the proximity between two service sectors may be higher for IT staff (if they use and possess very similar skills in different sectors) than for engineers (if their skills differ more depending on the specific sector of employment).

In this paper, we test our capability-based approach in simulations with a simple CGE model applied to an illustrative database for a Sub-Saharan African (SSA) economy. We selected a database for SSA since, compared to other regions, CGE models for this region tend to treat labor markets as competitive; i.e. they do not tend to consider non-competitive aspects like unionization and minimumwage legislation. ${ }^{4}$ Apart from the introduction of the proximity treatment, this is also how we treat the labor market. However, we consider the core innovation of our model as equally valid for other regions.

We proceed as follows: after a brief discussion of alternative approaches to labor mobility, Section 2 presents our approach. The approach is tested in Section 3 in a set of comparative-static CGE simulations of the effects of export price shocks for processed food products with alternative parameterizations of the labor market. Conclusions and a discussion of future research are presented in Section 4. A full mathematical statement of the CGE model is provided in an appendix and the model code and data are available as Supplementary Materials published with this paper.

\section{Method and data}

After a brief review of alternative treatments of labor mobility in CGE models and the broader labor economics literature in Section 2.1, Section 2.2 presents and analyzes the producer profit maximization problem on which we base the proximity-based formulation for labor mobility. It also includes a brief description of the simple CGE model into which it is embedded. (A full mathematical statement of the CGE model is in the appendix.) The illustrative database for the CGE application is presented in Section 2.3.

4 To exemplify, Boccanfuso and Savard (2007), Go et al. (2010), and Diao and Thurlow (2012) all assume competitive (but in some cases segmented) labor markets. CGE applications to Sub-Saharan Africa with non-competitive labor markets are very rare. Two examples, both related to minimum wages in South Africa, are Pauw and Leibbrandt (2012) and Erero (2016). 


\subsection{Alternative treatments of labor mobility in CGE models}

The CGE literature includes a large variety of treatments of the labor market, including labor mobility, which is the focus of this paper. ${ }^{5}$ As a reference point, it may be helpful to remind the reader of the relatively standard and simple CGE treatment of labor that is found in Lofgren et al. (2002). In this model, for each labor type (one or more, often categorized on the basis of education or "skill"), (a) the demand side is represented by first-order conditions for producer profitmaximization in the form of a value-added function and an equation that, for each production sector, imposes equality between the wage and the marginal value product of labor; (b) the quantity of labor supplied for employment is exogenous; and (c) a labor market equilibrium condition imposes equality between quantities demanded and supplied, an outcome that is realized via adjustments in an economy-wide wage variable. Labor is measured in physical units (e.g., number of full-time workers employed during one year). Base-year wages, which vary across activities, are computed on the basis of data on labor incomes (from the SAM) and employment quantities. For any labor type, this market-clearing mechanism does not change base-year relative wages by sector; it merely imposes a uniform scaling of the wages across all activities. Each labor type is perfectly mobile across the activities in which it is employed; a worker that moves from one sector to another earns the same wage and is as productive as those who already work in the receiving sector.

The CGE literature includes alternative approaches that deviate from this simple formulation in various ways, including the treatment of labor supply (which alternatively may be endogenous, as a point on a wage curve or driven by utility-maximizing household decisions), and sectoral wage differences (which vanish if in every employing sector, one unit of each labor type is defined as the quantity that earns a wage of one). An additional dimension of variation lies in the treatment of value-added, where different functional forms and nestings of labor and other factors have been used.

With regard to labor mobility, the focus of this paper, instead of perfect mobility, different types of segmentation are common with each segment including one or more activities. Segments may either be watertight compartments or allow for imperfect mobility (migration) between segments. According to one type of segmentation, labor-demanding activities are classified as rural or urban. The treatment of migration between the two areas may be based on the Harris-

${ }^{5}$ Boeters and Savard (2013) review the literature on labor markets in CGE models; their discussion of labor market coordination and heterogeneity (pp. 1679-1706) covers some of the issues addressed here. Annabi (2003) reviews the endogenization of labor supply, and the modeling of unions and efficiency wages. CGE analyses that present and apply approaches that deviate from the standard competitive market model are found in Thierfelder and Shiells (1997), and Maechler and Roland-Holst (1997). 
Todaro model with urban unemployment and migration ensuring equality between the rural wage and the expected urban wage; in the presence of urban unemployment, the wage in urban areas is fixed and therefore not free to clear the urban labor market (Dervis et al., 1982, pp. 178-180). ${ }^{6}$ Apart from the assumption of urban unemployment, the rural-urban migration model is in the same spirit as the formulation in Lofgren et al. (2002; described above) in the sense that, in both cases, in response to shocks, labor would be reallocated to maintain exogenous relative wage differences. Under a related approach, proposed by Flaig (2014, pp. 119-121), labor migrates to pools linked to multiple segments (with perfect mobility within each pool) or between pairs of segments, with each segment representing labor employed in one or more sectors. In both cases, migration depends on relative wage changes in different segments and response elasticities. In the GTAP model, the allocation of labor and other factors with imperfect mobility (which are "sluggish") is determined by a constant-elasticity-oftransformation (CET) function, with the allocations responding to changes in relative wages across activities (Hertel and Tsigas, 1997, pp. 51-52). Like formulations with labor units derived from normalization of wages to unity, the units of labor employed in different sectors do not correspond to physical units.

A review of the econometric labor economics literature indicates that, as opposed to the CGE literature, it has paid little attention to sectors. Its canonical model for wage (and inequality) analysis disaggregates labor on the basis 'skills' (in practice a small number, sometimes proxied by educational attainment) without any explicit reference to the sector dimension (Acemoglu and Autor 2011, pp. 1096-1118). As with CGE models, their model is in the neoclassical tradition. Wage changes for different skills depend on changes in labor market supplies and demands, the latter influenced by technological change. Implicitly (in the absence of any reference to sectors), the canonical model views labor in each skill group as perfectly mobile across sectors, i.e. in line with the most common assumption in CGE modeling.

\subsection{A proximity-based approach to labor segmentation}

This section first presents the static producer profit maximization problem with a proximity-based formulation for labor mobility. Subsequently, we also briefly describe the simple CGE model that is used in Section 3 and incorporates this labor

${ }^{6}$ Empirically, rural-urban segmentation is problematic: available data do not permit sectors to be split into rural and urban as, to varying degrees, production in all sectors takes place both in rural and urban areas. If this is linked to household disaggregation (inside the model or in a microsimulation module), then a further complication is that workers residing in rural (urban) areas may work in urban (rural) areas. The assumption of the Harris-Todaro model that rural labor is fully employed is also problematic and in sharp contrast with what is assumed in the Lewis model with unlimited supplies of labor (Lewis 1954). 
formulation. (See the appendix for a full mathematical statement of the CGE model.) The proposed treatment is inspired by the classical transportation model. ${ }^{7}$ In this model, the cost of transporting a set of items from supply to demand depots is minimized subject to demand and supply constraints, with a transportation cost of zero when the demand and supply depots are in the same location. In our approach, the items are physical units of labor and the unit transportation costs are replaced by efficient employment losses driven by distance (or proximity) measures, inspired by the PS literature. In both settings, the extent to which a demand location draws on different supplies depends on the market wage or price in the supply location and the loss that is imposed when a good or a unit of labor is relocated.

In mathematical terms, the optimization problem of the producer in destination activity $a$ may be stated as: ${ }^{8}$

$$
\begin{gathered}
\text { maximize } p_{a} \cdot Q_{a}-\sum_{f} \sum_{a^{\prime}} w f a s_{f, a^{\prime}} \cdot Q F A A_{f, a^{\prime}, a} \\
\text { subject to } \\
Q_{a}=\alpha_{a}\left[\sum_{f} \delta_{f, a} \cdot Q F_{f, a}^{-\rho}\right]^{\frac{-1}{\rho}} \\
Q F_{f, a}=\sum_{a^{\prime}} \varphi_{f, a^{\prime}, a} \cdot Q F A A_{f, a^{\prime}, a} \\
Q F A A_{f, a^{\prime}, a} \geq 0
\end{gathered}
$$

where $p_{a}$ is output price; $Q_{a}$ output quantity; $w f a s_{f, a^{\prime}}$ market wage per physical unit of factor $f$ linked to source activity $a^{\prime} ; Q F A A_{f, a^{\prime}, a}$ the physical quantity of $f$ from source activity $a^{\prime}$ allocated to current activity $a ; \alpha_{a}, \delta_{f, a}$, and $\rho$ CES function parameters for efficiency, factor shares, and exponent, respectively; $Q F_{f, a}$ employed quantity of factor $f$ in efficiency units in activity $a ; \varphi_{f, a^{\prime}, a}$ proximity

7 See Thompson and Thore (1992, pp. 9-21) for a detailed textbook presentation of the transportation model and its optimality conditions. A comparison to the conditions of the producer problem of this section highlights the parallels between, on one hand, transportation costs and goods movement in the transportation model and, on the other hand, efficiency losses and labor movements in our model.

${ }^{8}$ To simplify, this mathematical statement suppresses domain controls, and the activity subscript for the exponent $\rho$. This discussion also abstracts from two features of the CGE model that is applied model in Section 3: intermediate inputs, and exogenous relative wage differences between activities. 
between any source activity $a^{\prime}$ and the current activity $a$ with respect to factor $f$ $\left(0<\varphi_{f, a^{\prime}, a} \leq 1\right) .{ }^{9}$

In words, the objective function (1) defines profits as the difference between output revenue and factor costs, the latter defined as the sum of employed physical factor units from different source activities $a^{\prime}$ multiplied by related wages. The constraints, subject to which profits are maximized, consist of a CES function that defines output as a function of efficient factor quantities (2); a linear equation that defines efficient factor quantities as the sum of physical quantities multiplied by proximities between source activities $a^{\prime}$ and the destination activity $a$ (3); and nonnegativity constraints on factor reallocation (4). Note that, for the proximity parameters, a value of 1 is used for the special case where $a=a^{\prime}$, i.e., the case where labor stays in each original activity or where two activities, $a$ and $a^{\prime}$, are considered identical in terms of required worker capabilities. For factors without this reallocation mechanism (in our case non-labor factors), the proximity parameter is 1 for all relevant $a-a^{\prime}$ mappings, putting them in the same, economy-wide pool.

The Lagrangian of the optimization problem, $L$, may be expressed as:

$$
\begin{aligned}
L=p_{a} \cdot Q_{a}- & \sum_{f} \sum_{a^{\prime}} w f a s_{f, a^{\prime}} \cdot Q F A A_{f, a^{\prime}, a}+V_{a}\left[\alpha_{a}\left[\sum_{f} \delta_{f, a} \cdot Q F_{f, a}^{-\rho}\right]^{\frac{-1}{\rho}}-Q_{a}\right] \\
& +\sum_{f} W F A D_{f, a}\left[\sum_{a^{\prime}} \varphi_{f, a^{\prime}, a} \cdot Q F A A_{f, a^{\prime}, a}-Q F_{f, a}\right]
\end{aligned}
$$

where $V_{a}$ is the shadow price of output and $W F A D_{f, a}$, the efficiency-unit shadow wage (or rent) of factor $f$ in (destination) activity $a$, henceforth referred to as the efficiency wage. ${ }^{10}$ The first-order conditions may be rendered as:

$$
\begin{gathered}
\frac{\partial L}{\partial Q_{a}}=p_{a}-V_{a}=0 \\
\frac{\partial L}{\partial Q F_{f, a}}=\left(\frac{-1}{\rho}\right) V_{a} \cdot \alpha_{a}\left[\sum_{f^{\prime}} \delta_{f^{\prime}, a} \cdot Q F_{f^{\prime}, a}^{-\rho}\right]^{\frac{-1}{\rho}-1}\left[(-\rho) \delta_{f, a}\right. \\
\left.\cdot Q F_{f, a}^{-\rho-1}\right]-W F A D_{f, a}=0 \\
\frac{\partial L}{\partial Q F A A_{f, a^{\prime}, a}}=-w f a s_{f, a^{\prime}}+W F A D_{f, a} \cdot \varphi_{f, a^{\prime}, a} \leq 0
\end{gathered}
$$

9 Note that upper-/lower-case Latin letters are used for the variables that are endogenous/exogenous to the producer. In the CGE model, two of these exogenous variables, $p_{a}$ and $w$ fas $_{f, a^{\prime}}$, are endogenous.

10 The shadow wage represents the marginal value of the factor, i.e. on the margin, the increase in producer profit per additional unit of the factor, using the factor units in the production function. In most CGE models, it is simply the market wage. 


$$
\begin{gathered}
Q F A A_{f, a^{\prime}, a} \geq 0 \\
Q F A A_{f, a^{\prime}, a}\left(-w_{f a s_{f, a^{\prime}}}+W F A D_{f, a} \cdot \varphi_{f, a^{\prime}, a}\right)=0 \\
\frac{\partial L}{\partial V_{a}}=\alpha_{a}\left[\sum_{f} \delta_{f, a} \cdot Q F_{f, a}^{-\rho}\right]^{\frac{-1}{\rho}}-Q_{a}=0 \\
\frac{\partial L}{\partial W F A D_{f, a}}=\sum_{a^{\prime}} \varphi_{f, a^{\prime}, a} \cdot Q F A A_{f, a^{\prime}, a}-Q F_{f, a}
\end{gathered}
$$

Using (5) to substitute for $V_{a}$ in (6), noting that $(-1 / \rho)(-\rho)=1$, and rearranging the remaining equations permits us to summarize the first-order conditions for producer profit maximization as follows:

$$
\begin{gathered}
p_{a} \cdot \alpha_{a}\left[\sum_{f^{\prime}} \delta_{f^{\prime}, a} \cdot Q F_{f^{\prime}, a}^{-\rho}\right]^{\frac{-1}{\rho}-1}\left[\delta_{f, a} \cdot Q F_{f, a}^{-\rho-1}\right]=W F A D_{f, a} \\
w f a s_{f, a^{\prime}} \geq W F A D_{f, a} \cdot \varphi_{f, a^{\prime}, a} \\
Q F A A_{f, a^{\prime}, a} \geq 0 \\
Q F A A_{f, a^{\prime}, a}\left(W F A D_{f, a} \cdot \varphi_{f, a^{\prime}, a}-w f a s_{f, a^{\prime}}\right)=0 \\
Q_{a}=\alpha_{a}\left[\sum_{f} \delta_{f, a} \cdot Q F_{f, a}^{-\rho}\right]^{\frac{-1}{\rho}} \\
Q F_{f, a}=\sum_{a^{\prime}} \varphi_{f, a^{\prime}, a} \cdot Q F A A_{f, a^{\prime}, a}
\end{gathered}
$$

Equations 12-17 all appear in the CGE model, which is implemented as a mixedcomplementarity problem. ${ }^{11}$ Equation 12, a familiar condition for profit maximization, states that, at optimum, the marginal value product of labor in activity $a$ equals the wage, in this case the efficiency wage $\left(W F A D_{f, a}\right)$ since the production function uses efficiency units. Equation 13 imposes that, at optimum, the physical wage in $a^{\prime}\left(w f a s_{f, a^{\prime}}\right)$ has to be larger than or equal to the proximityadjusted efficiency wage $\left(W F A D_{f, a} \cdot \varphi_{f, a^{\prime}, a}\right)$. The labor quantities allocated from any $a^{\prime}$ to $a$ have to be non-negative (14). In equation 15 , for any allocation that takes place (is positive), the parenthesized expression with wage terms must be zero,

${ }^{11}$ The model is implemented in the GAMS software using the PATH solver. 
i.e., equation 13 must hold as an equality. The remaining two equations define the value-added function (16) and the link between labor hiring in efficiency units (on the left) to labor hiring in physical units (on the right) (17)

In order to see the economic logic behind and implications of equations 13 and 15, it may help to restate equation 13 as:

$$
\frac{\operatorname{wfas}_{f, a^{\prime}}}{\varphi_{f, a^{\prime}, a}} \geq W F A D_{f, a}
$$

If labor in $a^{\prime}$ is allocated to $a\left(Q F A A_{f, a^{\prime}, a}>0\right)$, then the equality between the leftand right-hand sides of (13') imposed by equation 15 means that the physical wage in the location of origin $a^{\prime}$, adjusted for the proximity parameter (the left side), equals the efficiency wage of labor in $a$ (the right side). This shows that activity $a$ allocates its hiring of labor from different sources so that the wage per efficiency unit of labor is equal across all sources. It means that activities pay less efficient workers a lower wage per physical unit. Drawing on equation 13', if a employs workers from two sources, $a^{\prime}$ and $a^{\prime \prime}$, and the proximity of $a^{\prime}$ is higher $\left(\varphi_{f, a^{\prime}, a}>\right.$ $\left.\varphi_{f, a^{\prime \prime}, a}\right)$, then, given $\quad W F A D_{f, a}=w f a s_{f, a^{\prime}} / \varphi_{f, a^{\prime}, a}=w f a s_{f, a^{\prime \prime}} / \varphi_{f, a^{\prime \prime}, a^{\prime}}$ $w_{f a s_{f, a^{\prime}}} / w f a s_{f, a^{\prime \prime}}=\varphi_{f, a^{\prime}, a} / \varphi_{f, a^{\prime \prime}, a}>1$.

On the other hand, for the case where workers from $a^{\prime}$ are not hired in $a$ $\left(Q F A A_{f, a^{\prime}, a}=0\right)$, equation 15 permits the right-hand side of equation $13^{\prime}$ to be strictly larger than the left-hand side. This means that, after corrected for low efficiency (a low proximity), a worker from $a^{\prime}$ requires a wage that is too high to be competitive in activity $a$. The implication is that efficiency-based wage setting stacks the cards against reallocation of labor from $a^{\prime}$ to $a$ if the proximity is low (strong misfit between the capabilities of the worker associated with $a^{\prime}$ and those required in $a) \cdot{ }^{12,13}$

The simulations in Section 3 use a simple static CGE model into which the proximity-based labor treatment is embedded. Apart from the labor treatment (which is based on equations 12-17), the CGE model is typical of models of small open economies with optimizing behavior for households and producers,

12 With regard to optimal outcomes, they do not include the case where $\operatorname{wfas}_{f, a^{\prime}} / \varphi_{f, a^{\prime}, a}<$ $W F A D_{f, a}$ since, if so, profits could be increased by hiring more labor from $a^{\prime}$ in $a$; i.e. after correction for efficiency losses, the wage paid for labor from $a^{\prime}$ is below the labor efficiency wage for $a$.

13 Similarly, willingness to pay a higher wage to workers already in their current employment is also generated by labor market insider-outsider theories. However, as opposed to our model, the focus is here on firms (not sectors) and the reasons are different: labor turnover costs among which lower productivity due to absent skills is only one part (cf. Lindbeck and Snower, 1988). 
domestic markets for commodities and factors cleared by flexible prices and wages, respectively, and a government that consumes, saves, taxes, and both receives and pays transfers. With regard to its treatment of factors, in distinction from the producer maximization problem, the CGE model also requires equilibrium conditions for factor markets, which are defined over $f$ and $a^{\prime}$ (one condition for each factor stock and activity of origin). These conditions may be stated as follows:

$$
\sum_{a} Q F A A_{f, a^{\prime}, a}=\overline{Q F A S}_{f, a^{\prime}}
$$

where $\overline{Q F A S}_{f, a^{\prime}}$ is the available physical quantity of factor $f$ that has the capabilities required in source activity $a^{\prime}$. The condition imposes equality between this quantity and the sum of the physical quantities of labor $f$ from $a^{\prime}$ that are allocated to any activity $a$. It is cleared by the wage variable, $w f a s_{f, a^{\prime}}$, which is exogenous in the producer model but endogenous (and in upper case) in the CGE model.

\subsection{Data}

The bulk of the dataset for our model consists of a social accounting matrix (SAM) and sectoral employment quantities (both for the simulation base-year), complemented by a set of elasticities (for production, consumption, and trade). Due to our proximity-based treatment, additional data is needed for the proximity parameter. We will here present the model database with special emphasis on the construction of the data for the proximity parameter.

In this application, the SAM is designed to capture the sectoral structure of an SSA country that is not strongly reliant in natural resource exports. ${ }^{14}$ The SAM is used to define base-year values for the bulk of the model parameters, including production technologies, sources of commodity supplies (domestic output or imports), demand patterns (for household and government consumption, investment and exports), transfers between different institutions, and tax rates. The disaggregation of our country SAM coincides with that of the rest of the model database. As shown in Table 1, it is disaggregated into 23 sectors (activities and commodities) - 3 in agriculture, 2 in mining, 13 in manufacturing, and 7 in services - with each activity producing a single commodity for which it is the only domestic producer. The factors are split into labor, private capital, and natural resources (5 types: agricultural land, forestry land, fishing resources, and two natural resources used in extractive industries). The institutions are split into households, government, and the rest of world. A set of auxiliary accounts cover the different tax instruments as well as trade and transport margins on domestic sales, imports and exports.

\footnotetext{
${ }^{14}$ Specifically, our SSA SAM is based on the 2010 supply and use tables for Uganda.
} 
Table 1. Disaggregation of SSA country CGE and SAM.

\begin{tabular}{|c|c|c|c|c|}
\hline $\begin{array}{l}\text { Category - \# } \\
\text { Sectors } \\
\text { (activities and } \\
\text { commodities) } \\
(25)\end{array}$ & & Item & Category - \# & Item \\
\hline \multirow{25}{*}{$\begin{array}{l}\text { Sectors } \\
\text { (activities and } \\
\text { commodities) } \\
(25)\end{array}$} & \multirow[t]{3}{*}{ Agriculture (3) } & Agriculture & \multirow[t]{7}{*}{ Factors (7) } & Labor \\
\hline & & Forestry & & Private capital \\
\hline & & Fishing & & Land \\
\hline & \multirow[t]{2}{*}{ Mining (2) } & Petroleum and gas & & Timber \\
\hline & & Mining & & Fish \\
\hline & \multirow{13}{*}{$\begin{array}{l}\text { Manufacturing } \\
\text { (13) }\end{array}$} & Food & & Extractive res in Pet and gas \\
\hline & & Beverages & & Extractive res in Mining \\
\hline & & Tobacco products & Institutions & Households \\
\hline & & Textiles and leather & (3) & Government \\
\hline & & Wood & & Rest of the world \\
\hline & & Paper & Auxiliary & Taxes on production \\
\hline & & Refined petroleum products & accounts (7) & Taxes on sales \\
\hline & & Chemical products & & Taxes on imports \\
\hline & & Rubber and plastic & & Taxes on income \\
\hline & & Non-metalic mineral products & & Trade and transp marg, dom \\
\hline & & Metal products & & Trade and transp marg, imp \\
\hline & & Machinery and vehicles & & Trade and transp marg, exp \\
\hline & & Other manufactures & \multirow{8}{*}{$\begin{array}{l}\text { Savings and } \\
\text { Investment } \\
\text { (4) }\end{array}$} & Savings \\
\hline & \multirow[t]{7}{*}{ Services (7) } & Electricity and gas & & Private (non-government) \\
\hline & & Construction & & Government \\
\hline & & Trade, hotels and resturants & & Stock change \\
\hline & & Transport & & \\
\hline & & Communications & & \\
\hline & & Government & & \\
\hline & & Other services & & \\
\hline
\end{tabular}

Source: Authors' elaboration.

On the basis of the SAM data, Table 2 summarizes the sectoral structure of the illustrative SSA economy: sectoral shares in value-added, production, employment, exports and imports, as well as the split of domestic sectoral supplies between exports and domestic sales, and domestic sectoral demands between imports and domestic output. For instance, while (primary) agriculture represents a significant share of employment (around 66 percent), its shares of value added (VA), production, and exports are much smaller (in the range of 15-25 percent). The share of its output that is exported is around 10 percent while only some 5 percent of domestic demands are met via imports. 
Journal of Global Economic Analysis, Volume 2 (2017), No. 1, pp. 120-165.

Table 2. Sectoral structure of illustrative SSA country economy (percent).

\begin{tabular}{|c|c|c|c|c|c|c|c|}
\hline Sector & $\begin{array}{l}\text { Value } \\
\text { added }\end{array}$ & Production & Employment & Exports & Imports & $\begin{array}{r}\text { Exports- } \\
\text { Output } \\
\text { ratio }\end{array}$ & $\begin{array}{r}\text { Imports- } \\
\text { Demand } \\
\text { ratio } \\
\end{array}$ \\
\hline Agriculture & 24.6 & 15.9 & 59.7 & 21.3 & 4.6 & 10.2 & 4.8 \\
\hline Forestry & 4.6 & 3.1 & 5.4 & 0.0 & 0.0 & 0.1 & 0.1 \\
\hline Fishing & 1.3 & 0.8 & 0.9 & 3.9 & 0.0 & 33.0 & 0.4 \\
\hline Petroleum and gas & 0.1 & 0.1 & 0.0 & 0.0 & 0.0 & 0.1 & 0.1 \\
\hline Mining & 1.1 & 1.1 & 0.2 & 0.6 & 1.4 & 3.5 & 16.8 \\
\hline Food & 7.2 & 11.3 & 2.9 & 12.6 & 7.0 & 9.0 & 10.5 \\
\hline Beverages & 0.9 & 1.7 & 0.1 & 2.9 & 1.1 & 13.3 & 14.3 \\
\hline Tobbaco products & 0.1 & 0.2 & 0.0 & 0.3 & 0.2 & 15.1 & 39.3 \\
\hline Textiles and leather & 1.0 & 1.0 & 0.2 & 8.4 & 4.9 & 56.4 & 64.4 \\
\hline Wood & 0.0 & 0.5 & 0.0 & 0.4 & 0.2 & 6.5 & 5.7 \\
\hline Paper & 0.1 & 0.1 & 0.0 & 0.5 & 1.9 & 30.9 & 63.7 \\
\hline Refined petroleum products & 0.0 & 0.1 & 0.0 & 1.0 & 16.2 & 97.7 & 84.7 \\
\hline Chemical products & 1.1 & 1.3 & 0.1 & 3.1 & 11.1 & 17.2 & 59.2 \\
\hline Rubber and plastic & 0.2 & 0.2 & 0.0 & 1.0 & 2.1 & 33.3 & 68.8 \\
\hline Non-metalic mineral products & 0.8 & 1.2 & 0.1 & 3.1 & 2.6 & 20.3 & 29.4 \\
\hline Metal products & 0.8 & 1.3 & 0.1 & 5.4 & 8.2 & 34.7 & 59.0 \\
\hline Machinery and vehicles & 0.1 & 0.2 & 0.0 & 2.7 & 27.4 & 98.5 & 99.9 \\
\hline Other manufactures & 0.6 & 1.0 & 0.1 & 0.9 & 1.9 & 7.3 & 23.4 \\
\hline Electricity and gas & 0.5 & 0.4 & 0.1 & 0.5 & 0.1 & 10.4 & 3.8 \\
\hline Construction & 6.6 & 11.3 & 2.0 & 0.0 & 0.0 & 0.0 & 0.0 \\
\hline Trade, hotels and resturants & 14.9 & 17.2 & 8.2 & 15.8 & 2.1 & 8.3 & 1.9 \\
\hline Transport & 2.5 & 2.3 & 1.3 & 2.8 & 3.9 & 10.9 & 21.4 \\
\hline Communications & 3.7 & 3.6 & 0.8 & 0.0 & 0.0 & 0.0 & 0.0 \\
\hline Government & 3.5 & 3.8 & 3.5 & 8.1 & 0.5 & 19.3 & 2.2 \\
\hline Other services & 23.8 & 20.3 & 14.1 & 4.6 & 2.4 & 2.1 & 1.7 \\
\hline Total & 100.0 & 100.0 & 100.0 & 100.0 & 100.0 & 8.1 & 15.8 \\
\hline
\end{tabular}

Note: The columns Value added, Production, Employment, Exports, and Imports show the shares (in percent) of each sector in the country totals. The columns Exports-output ratio and Importsdemand show exports and imports as shares (in percent) of total sector output and total domestic demand, respectively.

Table 3 shows the factor shares in total sectoral value added. For example, the table shows that agriculture is relatively intensive in the use of labor; this information will be useful to analyze the results from the CGE simulations. 
Table 3. Sectoral factor intensity of illustrative SSA economy (percent)

\begin{tabular}{lrrrr}
\hline Sector & Labor & Prv Capital & Nat Res & Total \\
\hline Agriculture & 73.7 & 15.0 & 11.3 & 100.0 \\
Forestry & 36.0 & 0.3 & 63.7 & 100.0 \\
Fishing & 21.1 & 0.2 & 78.7 & 100.0 \\
Petroleum and gas & 27.3 & 38.1 & 34.6 & 100.0 \\
Mining & 27.3 & 51.5 & 21.2 & 100.0 \\
\hline Food & 68.9 & 31.1 & 0.0 & 100.0 \\
Beverages & 23.0 & 77.0 & 0.0 & 100.0 \\
Tobacco products & 66.1 & 33.9 & 0.0 & 100.0 \\
Textiles and leather & 39.6 & 60.4 & 0.0 & 100.0 \\
Wood & 14.6 & 85.4 & 0.0 & 100.0 \\
Paper & 27.3 & 72.7 & 0.0 & 100.0 \\
Refined petroleum products & 9.3 & 90.7 & 0.0 & 100.0 \\
Chemical products & 19.2 & 80.8 & 0.0 & 100.0 \\
Rubber and plastic & 17.6 & 82.4 & 0.0 & 100.0 \\
Non-metalic mineral products & 17.4 & 82.6 & 0.0 & 100.0 \\
Metal products & 17.9 & 82.1 & 0.0 & 100.0 \\
Machinery and vehicles & 15.1 & 84.9 & 0.0 & 100.0 \\
Other manufactures & 30.0 & 70.0 & 0.0 & 100.0 \\
\hline Electricity and gas & 41.6 & 58.4 & 0.0 & 100.0 \\
Construction & 50.7 & 49.3 & 0.0 & 100.0 \\
Trade, hotels and resturants & 49.6 & 50.4 & 0.0 & 100.0 \\
Transport & 48.8 & 51.2 & 0.0 & 100.0 \\
Communications & 19.6 & 80.4 & 0.0 & 100.0 \\
Government & 100.0 & 0.0 & 0.0 & 100.0 \\
Other services & 52.9 & 47.1 & 0.0 & 100.0 \\
\hline Total & 55.7 & 37.3 & 7.0 & 100.0 \\
\hline
\end{tabular}

Source: Authors' calculations based on illustrative SSA country SAM.

Compared to a standard CGE application, additional data is needed for the proximity parameter. As indicated in the preceding section, the values for this parameter should measure the extent to which a worker that belongs to activity $a^{\prime}$ has the capabilities required from workers in a destination activity $a$; in other words, it should measure the efficiency of workers from $a^{\prime}$ in $a$ compared to workers that belong to $a$. Different approaches are possible and in the concluding section we highlight this as an important area for future research.

For the purposes of this paper, we found it convenient to draw on the PS approach, computing proximities on the basis of revealed comparative advantage 
(RCA) data computed from international trade data. ${ }^{15}$ In PS analysis, the proximity of one sector to another is the core indicator of how close the two sectors are in terms of the capabilities needed for competitive production. In this paper, we apply it to labor as an indicator of the closeness of the capabilities required in different sectors.

RCA measures the degree of comparative advantage by country, commodity, and time. A country has an RCA in commodity $c$ if the following indicator has a value above unity:

$$
R C A_{r, c, t}=\frac{\frac{E_{r, c, t}}{\sum_{c^{\prime}, E_{r, c^{\prime}, t}}}}{\frac{\sum_{r^{\prime}} E_{r^{\prime}, c, t}}{\sum_{r^{\prime}} \sum_{c^{\prime}} E_{r^{\prime}, c^{\prime}, t}}}=\frac{\frac{E_{r, c, t}}{\sum_{r^{\prime}, E_{r^{\prime}, c, t}}}}{\frac{\sum_{c^{\prime}} E_{r, c^{\prime}, t}}{\sum_{r^{\prime}} \sum_{c^{\prime}} E_{r^{\prime}, c^{\prime}, t}}}
$$

where $E$ stands for export value (in US\$) while the indices $r$ (or $\left.r^{\prime}\right), c$ (or $c^{\prime}$ or $c^{\prime \prime}$ ), and $t$ stand for countries ("regions"), commodities (often referred to as products, typically limited to goods), and years, respectively. ${ }^{16}$ We name the related binary 0-1 variable $r c a 01_{r, c, t}\left(r c a 01_{r, c, t}=0\right.$ if $R C A_{r, c, t}<1 ; r c a 01_{r, c, t}=1$ if $\left.R C A_{r, c, t} \geq 1\right)$. The term in the middle defines RCA as the ratio between the shares of commodity $c$ in country and world exports while the term on the right equivalently defines it as the ratio between the shares of the country in global exports of commodity $c$ and in total global exports.

The proximity between two commodities, $c$ and $c^{\prime}$, in time $t, \varphi_{c, c^{\prime}, t}\left(0 \leq \varphi_{c, c^{\prime}, t} \leq\right.$ 1 ) is derived from data on probabilities of simultaneously having $R C A_{r, c, t} \geq$ 1 and $R C A_{r, c^{\prime}, t} \geq 1$ :

$$
\varphi_{c, c^{\prime}, t}=\min \left\{P\left(\operatorname{rca01}_{c, t} \mid r c a 01_{c^{\prime}, t}\right), P\left(\operatorname{rca01}_{c^{\prime}, t} \mid r c a 01_{c, t}\right)\right\}
$$

where $P$ (the conditional probability) is computed using all countries $r$ in year $t$, and where

$$
r c a 01_{c, t}=\left\{\begin{array}{l}
1 \text { if } R C A_{r, c, t}>1 \\
0 \text { if } R C A_{r, c, t} \leq 1
\end{array}\right\}
$$

15 PS analysis, which was pioneered in Hausmann and Klinger (2006) and Hidalgo et al. (2007), offers a data-driven evaluation of the feasibility and desirability of alternative sectoral transformation options for a country, considering its initial export structure and the structure across a near complete set of country-level export data.

${ }^{16}$ In PS analysis, the indices $c$ and $i$ are typically used for country and product; in our CGE model and those of many others, $c$ is used for commodities (goods or services). In order to avoid confusion and to keep notation consistent throughout this study, we switch to $r$ for countries (or "regions"; this follows the example of GTAP) and use $c$ for commodities. It should also be noted that our CGE makes a distinction between commodities $c$ (outputs) and activities $a$ (producing outputs); in this application, there is a one-to-one mapping between the two. 
In our application, the proximity indicator is used as a measure of how close the capabilities of workers in a sector are from those required for full efficiency in other sectors; in the PS literature, it is used as a measure of a country's capabilities, also considering other inputs. The proximity indicator follows the disaggregation of the CGE database. For the commodities that it covers, we use the Comtrade export database. However, proximity data are also needed for sectors not covered by Comtrade. Non-Comtrade commodities are made up of services and a subset of goods (the latter including utilities and construction); all tend to be relatively non-traded. Given that, export data may not exist or be relevant to RCA measurement, we instead use GTAP value-added data. Given that our dataset has a one-to-one mapping between activities (production sectors) and commodities (outputs), it is straightforward to define RCA and proximity indicators using export data for one commodity subset and VA data for another commodity subset.

The computed raw proximity data between all pairs of commodities are shown in Table $4 .{ }^{17}$ Further, before the CGE implementation of these raw proximities, scaling was needed to generate empirically valid representations of labor market segmentation. ${ }^{18}$ This is part of the broader challenge of testing and improving the validity of CGE models in manners that consider the context of different types of applications.

17 A model with multiple labor categories would require multiple proximity matrices to permit proximity data to differ by labor category (for example, classified by educational attainment, skill, or occupation). For example, IT and human resources staff may have very small distances between sectors; other skilled tasks may be highly specialized.

${ }^{18}$ In our application in Section 3, the scaled proximity parameter, $\varphi_{a^{\prime}, a^{\prime}}$ used in the model is derived from the original raw proximity parameter using the following formula: $\varphi_{a^{\prime}, a}=$ $\varphi_{a^{\prime}, a}^{r a w}+\varphi^{\text {scal }} \cdot\left(1-\varphi_{a^{\prime}, a}^{r a w}\right)$, where $\varphi^{\text {scal }}$ is a factor-specific scaling parameter. The higher the value of the latter, the higher the scaled proximity. To ensure that $0 \leq \varphi_{a^{\prime}, a} \leq 1$, the scaling parameter should satisfy the following restriction: $-\varphi_{a^{\prime}, a}^{r a w} /\left(1-\varphi_{a^{\prime}, a}^{r a w}\right) \leq \varphi^{\text {scal }} \leq 1$. Note that $\lim _{\varphi^{s c a l} \rightarrow 1}\left(\varphi_{a^{\prime}, a}^{r a w}+\varphi^{\text {scal }} \cdot\left(1-\varphi_{a^{\prime}, a}^{r a w}\right)\right)=1$. If the non-scaled proximities are too low, simulated factor reallocation falls short of what is observed in practice; to make reallocation easier, the value of the scaling parameter should be within the following range: $0<\varphi^{\text {scal }} \leq 1$. Given current uncertainty about its value, it may be seen as the exogenous shift parameter that is used in the non-base simulations to explore the implications of different degrees of sensitivity of efficiency for potentially relocated labor to proximity. 
Table 4. Proximity between sectors in the illustrative SSA country SAM.

\begin{tabular}{|c|c|c|c|c|c|c|c|c|c|c|c|c|c|c|c|c|c|c|c|c|c|c|c|c|c|}
\hline & 1 & 2 & 3 & 4 & 5 & 6 & 7 & 8 & 9 & 10 & 11 & 12 & 13 & 14 & 15 & 16 & 17 & 18 & 19 & 20 & 21 & 22 & 23 & 24 & 25 \\
\hline 1 Agriculture & 1.00 & 0.48 & 0.49 & 0.23 & 0.46 & 0.80 & 0.46 & 0.36 & 0.44 & 0.39 & 0.23 & 0.25 & 0.20 & 0.260 & 0.31 & 0.43 & 0.10 & 0.16 & 0.48 & 0.46 & 0.640 & 0.57 & 0.46 & 0.26 & 0.23 \\
\hline 2 Forestry & 0.48 & 1.00 & 0.48 & 0.14 & 0.27 & 0.52 & 0.45 & 0.39 & 0.50 & 0.59 & 0.34 & 0.30 & 0.25 & 0.410 & 0.43 & 0.42 & 0.18 & 0.25 & 0.47 & 0.49 & 0.480 & 0.51 & 0.50 & 0.16 & 0.25 \\
\hline 3 Fishing & 49 & 0.48 & 1.00 & 0.22 & 0.39 & 0.51 & 0.54 & 0.49 & 0.46 & 0.37 & 0.29 & 0.22 & 0.24 & 0.270 & 0.34 & 0.31 & 0.17 & 0.27 & 0.34 & 43 & 0.460 & 0.32 & 0.40 & 0.32 & 0.32 \\
\hline 4 Petroleum and gas & 0.23 & 0.14 & 0.22 & 1.00 & 0.26 & 0.16 & 0.08 & 0.11 & 0.15 & 0.25 & 0.11 & 0.41 & 0.08 & 0.030 & 0.14 & 0.13 & 0.08 & 0.04 & 0.26 & 0.22 & 0.270 & 0.22 & 0.21 & 0.15 & 0.07 \\
\hline 5 Mining & 0.46 & 0.27 & 0.39 & 0.26 & 1.00 & 0.38 & 0.35 & 0.29 & 0.31 & 0.35 & 0.23 & 0.31 & 0.20 & 0.090 & 0.22 & 0.49 & 0.03 & 0.26 & 0.32 & 0.33 & 0.370 & 0.36 & 0.40 & 0.37 & 0.20 \\
\hline 6 Food & 0.80 & 0.52 & 0.51 & 0.16 & 0.38 & 1.00 & 0.52 & 0.43 & 0.49 & 0.44 & 0.26 & 0.30 & 0.25 & 0.330 & 0.39 & 0.36 & 0.10 & 0.26 & 0.49 & 0.51 & 0.56 & 0.57 & 0.46 & 0.28 & 0.25 \\
\hline $7 \mathrm{Bev}$ & 0.46 & 0.45 & 0.54 & 0.08 & 0.35 & 0.52 & 1.00 & 0.48 & 0.45 & 0.43 & 0.40 & 0.25 & 0.25 & 0.400 & 0.50 & 0.42 & 0.18 & 0.30 & 0.32 & 0.49 & 0.38 & 0.39 & 0.50 & 0.33 & 0.50 \\
\hline $8 \mathrm{Tob}$ & 0.36 & 0.39 & 0.49 & 0.11 & 0.29 & 0.43 & 0.48 & 1.00 & 0.51 & 0.48 & 0.26 & 0.21 & 0.26 & 0.420 & 0.45 & 0.31 & 0.18 & 0.45 & 0.28 & 0.39 & 0.37 & 0.32 & 0.44 & 0.24 & .34 \\
\hline $9 \mathrm{Tex}$ & 0.44 & 0.50 & 0.46 & 0.15 & 0.31 & 0.49 & 0.45 & 0.51 & 1.00 & 0.38 & 0.21 & 0.28 & 0.21 & 0.380 & 0.49 & 0.38 & 0.08 & 0.36 & 0.36 & 0.39 & 0.400 & 0.44 & 0.38 & 0.13 & 0.18 \\
\hline 10 Woo & 0.39 & 0.59 & 0.37 & 0.25 & 0.35 & 0.44 & 0.43 & 0.48 & 0.38 & 1.00 & 0.43 & 0.28 & 0.10 & 0.400 & 0.45 & 0.44 & 0.25 & 0.30 & 0.47 & 0.45 & 0.370 & 0.46 & 0.44 & 0.23 & .25 \\
\hline $11 \mathrm{~Pa}$ & 0.23 & 0.34 & 0.29 & 0.11 & 0.23 & 0.26 & 0.40 & 0.26 & 0.21 & 0.43 & 1.00 & 0.18 & 0.22 & 0.480 & 0.43 & 0.36 & 0.41 & 0.26 & 0.26 & .33 & 0.23 & 0.27 & 0.33 & 0.37 & 0.55 \\
\hline $12 \mathrm{Re}$ & 0.25 & 0.30 & 0.22 & 0.41 & 0.31 & 0.30 & 0.25 & 0.21 & 0.28 & 0.28 & 0.18 & 1.00 & 0.26 & 0.150 & 0.30 & 0.31 & 0.12 & 0.21 & 0.36 & ).39 & 0.19 & 0.37 & 0.38 & 0.24 & 0.18 \\
\hline $13 \mathrm{Ch}$ & 0.20 & 0.25 & D.24 & 0.08 & 0.20 & 0.25 & 0.25 & 0.26 & 0.21 & 0.10 & 0.22 & 0.26 & 1.00 & 0.330 & 0.30 & 0.16 & 0.26 & 0.30 & 0.11 & .27 & 0.15 & 0.19 & 0.25 & 0.38 & 0.45 \\
\hline $14 \mathrm{Ru}$ & 0.26 & 0.41 & 0.27 & 0.03 & 0.09 & 0.33 & 0.40 & 0.42 & 0.38 & 0.40 & 0.48 & 0.15 & 0.33 & 1.000 & 0.62 & 0.33 & 0.48 & 0.45 & 0.26 & ).39 & 0.21 & 0.34 & 0.40 & 0.30 & 0.52 \\
\hline $15 \mathrm{Nc}$ & 0.31 & 0.43 & 0.34 & 0.14 & 0.22 & 0.39 & 0.50 & 0.45 & 0.49 & 0.45 & 0.43 & 0.30 & 0.30 & 0.621 & 1.00 & 0.51 & 0.30 & 0.35 & 0.40 & .49 & 0.27 & 0.42 & 0.44 & 0.24 & 0.38 \\
\hline $16 \mathrm{M}$ & 0.43 & 0.42 & 0.31 & 0.13 & 0.49 & 0.36 & 0.42 & 0.31 & 0.38 & 0.44 & 0.36 & 0.31 & 0.16 & 0.330 & 0.51 & 1.00 & 0.24 & 0.31 & 0.53 & 0.53 & 0.35 & 0.49 & 0.50 & 0.20 & 0.29 \\
\hline $17 \mathrm{M}$ & 0.10 & 0.18 & 0.17 & 0.08 & 0.03 & 0.10 & 0.18 & 0.18 & 0.08 & 0.25 & 0.41 & 0.12 & 0.26 & 0.480 & 0.30 & 0.24 & 1.00 & 0.33 & 0.21 & 0.22 & 0.17 & 0.22 & 0.23 & 0.27 & 0.41 \\
\hline $18 \mathrm{Ot}$ & 0.16 & 0.25 & 0.27 & 0.04 & 0.26 & 0.26 & 0.30 & 0.45 & 0.36 & 0.30 & 0.26 & 0.21 & 0.30 & 0.450 & 0.35 & 0.31 & 0.33 & 1.00 & 0.26 & 0.31 & 0.17 & 0.29 & 0.27 & 0.22 & 0.31 \\
\hline $19 \mathrm{El}$ & 0.48 & 0.47 & 0.34 & 0.26 & 0.32 & 0.49 & 0.32 & 0.28 & 0.36 & 0.47 & 0.26 & 0.36 & 0.11 & 0.260 & 0.40 & 0.53 & 0.21 & 0.26 & 1.00 & 0.47 & 0.45 & 0.56 & 0.42 & 0.19 & 0.15 \\
\hline 20 Cons & 0.46 & 0.49 & 0.43 & 0.22 & 0.33 & 0.51 & 0.49 & 0.39 & 0.39 & 0.45 & 0.33 & 0.39 & 0.27 & 0.390 & 0.49 & 0.53 & 0.22 & 0.31 & 0.47 & 1.00 & 0.29 & 0.49 & 0.51 & 0.29 & 0.39 \\
\hline , hotels and resturants & 0.64 & 0.48 & 0.46 & 0.27 & 0.37 & 0.56 & 0.38 & 0.37 & 0.40 & 0.37 & 0.23 & 0.19 & 0.15 & 0.210 & 0.27 & 0.35 & 0.17 & 0.17 & 0.45 & 0.25 & 1.00 & 0.49 & 0.38 & 0.19 & 0.19 \\
\hline $22 \operatorname{Tr}_{\mathrm{c}}$ & 0.57 & 0.51 & 0.32 & 0.22 & 0.36 & 0.57 & 0.39 & 0.32 & 0.44 & 0.46 & 0.27 & 0.37 & 0.19 & 0.340 & 0.42 & 0.49 & 0.22 & 0.29 & 0.56 & 0.49 & 0.49 & 1.00 & 0.47 & 0.20 & 0.19 \\
\hline $23 \mathrm{Co}$ & 0.46 & 0.50 & 0.40 & 0.21 & 0.40 & 0.46 & 0.50 & 0.44 & 0.38 & 0.44 & 0.33 & 0.38 & 0.25 & 0.400 & 0.44 & 0.50 & 0.23 & 0.27 & 0.42 & 0.51 & 0.38 & 0.47 & 1.00 & 0.35 & 0.40 \\
\hline $24 \mathrm{Go}$ & 0.26 & 0.16 & 0.32 & 0.15 & 0.37 & 0.28 & 0.33 & 0.24 & 0.13 & 0.23 & 0.37 & 0.24 & 0.38 & 0.300 & 0.24 & 0.20 & 0.27 & 0.22 & 0.19 & 0.29 & 0.19 & 0.20 & 0.35 & 1.00 & 0.48 \\
\hline 25 Other services & 0.23 & 0.25 & 0.32 & 0.07 & 0.20 & 0.25 & 0.50 & 0.34 & 0.18 & 0.25 & 0.55 & 0.18 & 0.45 & 0.520 & 0.38 & 0.29 & 0.41 & 0.31 & 0.15 & 0.39 & 0.19 & 0.19 & 0.40 & 0.48 & 1.00 \\
\hline
\end{tabular}

Source: Authors' calculations based on Comtrade and GTAP 8 data.

In addition to the SAM and proximity data, our CGE model also requires (a) base-year estimates for sectoral employment levels, and (b) a set of elasticities (for production, consumption and trade). In order to estimate sectoral employment, we combined population data with estimates for sectoral employment shares in broad sectoral categories from World Bank (2016). In turn, elasticities were given a value based on the available evidence for comparable countries. For elasticities, the following values were used: (a) the elasticity of substitution among factors is in the 0.2-1.15 range, relatively low for primary sectors and relatively high for manufactures and services (see Narayanan et al. 2012); (b) the expenditure elasticities for household consumption were obtained from Seale et al. (2003); and (c) trade elasticities are 4 for both Armington and CET elasticities. ${ }^{19}$ Given the uncertainty with respect to our elasticity values, we conducted a systematic sensitivity analysis of our simulation results with respect to their values; it indicated that the results presented here are robust. ${ }^{20}$

${ }^{19}$ These CET and Armington elasticities may seem high. However, the size of responses to trade-related shocks depend not only on these trade elasticities but also on other aspects of the model, including the size of production responses which, in their turn, depend on (a) the mobility of labor and other factors; and (b) elasticities of factor substitution. Thus, a given trade-related shock may generate similar trade and production responses with a combination of high factor mobility and low trade elasticities or, alternatively, low factor mobility and high trade elasticities.

20 The results from the systematic sensitivity are published with this paper as Supplementary Material C. 


\section{Simulations}

\subsection{Scenarios}

This section presents the simulations and analyzes their results. The simulations consist of a base solution (which replicates the base-year economy) and a set of non-base scenarios. All scenarios are run under the assumption of fixed total employment. At the macro level, our CGE model - like others - requires the specification of the equilibrating mechanisms ("closures") for three macroeconomic balances: government, savings-investment, and the balance of payments. Unless specified otherwise, in all simulations the following macroeconomic closure rules are applied: (a) in order to ensure that the simulations are budget neutral, changes in income tax rates on households clear the government budget (i.e., compared to base values, no other changes in taxes or other revenue sources, domestic or foreign, are permitted); (b) in order to ensure that the simulations are neutral in terms of changes in country net foreign assets, foreign savings (the current account deficit) is fixed in foreign currency, an outcome that is achieved through changes in the real exchange rate; and (c) in order to ensure neutrality across the simulations in terms of investing for the future, real investment is fixed; as a result of this and given the fact that real government consumption also is fixed, change in real private consumption may be used to measure changes in aggregate welfare. With regard to non-labor factors, for all simulations we assume that they are sector-specific (no mobility between sectors).

The different non-base scenarios and their treatment of labor mobility are shown in Table 5. The non-base simulations explore how the impact of a terms-oftrade shock is influenced by alternative settings for labor proximities. Across all scenarios, we impose a 35 percent increase in the food export price. ${ }^{21}$ Given the sectoral structure described in Table 2 (e.g., the food industry has a relatively high export-to-output ratio), this shock serves to illustrate the working of the proposed approach to modeling labor mobility across sectors.

${ }^{21}$ In addition, sensitivity tests indicated that our qualitative findings were robust to alternative magnitudes for the shock: specifically, we tested the same five labor proximity settings for increases in the food export price in a range from 10 to -50 percent. The results from these additional scenarios are published with this paper as Supplementary Material B. 
Table 5. Definitions of non-base scenarios.

\begin{tabular}{l|l}
\hline $\begin{array}{l}\text { Name / degree of labor } \\
\text { mobility }\end{array}$ & Description \\
\hline zero & sector-specific labor due to very low proximities \\
\hline low & proximity parameters from Table 4 \\
\hline medium & $\begin{array}{l}\text { proximity scaling* by } 0.5, \text { reducing gap between } 1 \text { and } \\
\text { values in Table } 4 \text { by } 50 \% .\end{array}$ \\
\hline high & $\begin{array}{l}\text { proximity scaling* by } 0.75, \text { reducing gap between } 1 \text { and } \\
\text { parameters in Table } 4 \text { by } 75 \% .\end{array}$ \\
\hline perfect & integrated labor market (all proximities $=1)$ \\
\hline
\end{tabular}

Note: * The scaling factor is defined in footnote 22.

Source: Authors' elaboration.

\subsection{Results}

Tables 6-9 and Figures 1 and 2 summarize the results for the simulations, covering both the macro and sector levels. Overall, the results are regular and as expected. At the macro level (Table 6 and Figure 1), the higher the degree of mobility, the stronger the gains. For the zero mobility scenario, the gain in the food export price raises the value of exports, generating a balance of payments surplus and an equilibrating appreciation of the real exchange rate, which reduces the export volume, raises the import volume, and increases absorption, in this case private consumption since the other parts of absorption (investment and government consumption) are fixed in real terms. These changes take place without any changes in employment or production, i.e., given the assumption that non-labor factors are sector-specific, existing output is merely reallocated from exports to domestic sales.

Across all scenarios, the higher the degree of labor mobility, the stronger the gains in absorption and private consumption, indicating that a more flexible economy is better at reallocating resources to gain from (or mitigate losses due to) international price changes. ${ }^{22}$ Since it is able to focus on higher-valued exports, a flexible economy is able to maintain external balance with smaller export

${ }^{22}$ A higher trade deficit is more favorable in the sense that, for any given level of real GDP, it permits higher level of domestic final demands (absorption). In addition to the terms of trade gain and labor reallocation, in this set of simulations, the measured welfare gain is boosted because the favored sector (food) pays wages that are above the average. This is due to the fact that the equilibrium solutions (reflecting real world observations) retain observed wage gaps (in our model with fixed relative wage differences, a common formulation). Higher than average wages in certain sectors may compensate for a relatively high disutility from work in these sectors; however, this is not reflected in the model or in the welfare measures (based on private consumption) that are presented. 
quantities and higher import quantities. GDP at factor cost increases slightly for the non-zero-mobility scenarios due to the fact that, in the food sector, which accounts for almost all output and employment increases, marginal productivity of labor (and wages) are above average. ${ }^{23}$

For the real exchange rate, the expected result is that higher mobility would reduce the appreciation needed to eliminate the surplus in the current account; this is indeed the result across the simulations with non-zero labor mobility. However, the lowest real appreciation is registered for the simulation with zero mobility; this is due to the fact that, for this simulation, the absence of employment changes prevents output and export increases for the food sector that drastically increase the current account surplus and, given this, the need for real appreciation.

Labor reallocation to the food sector is the reason behind the absorption gains beyond what is achieved for the zero mobility scenario - the higher the proximity, the stronger the mobility, the reallocation, and the ability of the economy to export at more favorable terms with the benefits appearing in higher imports and absorption. Table 7 shows the shares of the workers initially employed in different sectors that, in response to the shock, move to the food sector. As expected, when labor mobility increases (among other things meaning that other sectors are in closer proximity to the food industry), we see labor moving into the food industry from a larger number of sectors. For example, labor moves from four and ten sectors in the medium and high scenarios, respectively.

From a different angle, Figure 2 displays the percent changes for output, efficient employment, and physical employment in the food sector for the different scenarios. ${ }^{24}$ Except for the case with perfect mobility, the quantity of labor in efficiency units that moves to the food sector is smaller than the physical quantity due to the loss in efficiency. The fact that certain sectors are more prone to release labor to food is in part determined by the proximity data - other manufacturing sectors, such as beverages, are relatively close to food. In fact, Table 4 in Section 2.3 shows that beverages is a sector in close proximity to the food processing industry. However, the pattern of labor reallocation is also influenced by other factors, including the extent to which the output of the different sectors is tradable - as a result of the real appreciation, non-food sectors that are relatively tradable lose more than others in terms of relative profitability.

Tables 8 and 9 show the changes in sectoral output and employment (both physical and efficient), respectively. Not surprisingly, the major backward link of

${ }^{23}$ Given the current set of assumptions, real GDP at factor cost changes due to (a) losses in productivity when labor moves between sectors; and (b) exogenous wage differentials across sectors. Labor movements between two sectors with a linking proximity of 1 (no productivity loss) and identical wages, do not change GDP.

${ }^{24}$ Under perfect mobility, we can compute employment changes but we cannot single out the sectors of origin and destination for labor movements. 
food is with agriculture. In the base-year dataset the food industry accounts for 27 percent of total demand for agricultural output. ${ }^{25}$ As the increase in food production increases with increased mobility, the positive impact on intermediate food demands for agricultural output comes to dominate the negative impact on agricultural exports from appreciation. Interestingly, this input-output relation between agriculture and food dominates the labor reallocation from agriculture to food that would have been expected given the close proximity between them (see Table 4 in Section 2.3).

In Table 9, all contracting activities show the same negative changes in physical and efficiency units since all of the departing workers were assigned to the activities from they depart (their proximities were equal to one, i.e., $a=a^{\prime}$ ). On the other hand, given that the proximities for movements from contracting to expanding activities here always are less than one, the positive employment changes are always smaller in efficiency units than in physical units.

Table 6. Real macro indicators (percent change from base).

\begin{tabular}{lrrrrrr}
\hline Item & base year* & zero & low medium & high & perfect \\
\hline Absorption & 109.7 & 0.9 & 1.4 & 1.7 & 1.9 & 2.0 \\
Private consumption & 77.1 & 1.3 & 2.1 & 2.5 & 2.7 & 2.8 \\
Exports & 16.0 & 4.3 & 4.0 & 3.9 & 3.4 & 2.9 \\
Imports & 25.7 & 6.5 & 7.1 & 7.7 & 7.9 & 8.3 \\
GDP at factor cost & 91.4 & 0.0 & 0.5 & 0.8 & 1.0 & 1.0 \\
\hline Real exchange rate & 1 & -4.5 & -8.1 & -7.5 & -7.0 & -6.9 \\
Note: ${ }^{*}$ In this column, the unit is \% of GDP at market prices except for the real exchange rate, which is \\
indexed to 1.
\end{tabular}

Source: Authors' calculations.

${ }^{25}$ Other major demands for agricultural output is for household consumption, exports, and for use in the "Trade, hotels and restaurants" sector. 
Journal of Global Economic Analysis, Volume 2 (2017), No. 1, pp. 120-165.

Table 7. Share of labor initially employed in activity $a$ (column) allocated to food processing (percent).

\begin{tabular}{lrrr}
\hline Activity & low & medium & high \\
\hline Agriculture & 0.4 & 0.4 & 0.0 \\
Forestry & 0.0 & 0.0 & 0.0 \\
Fishing & 0.0 & 0.0 & 0.0 \\
Petroleum and gas & 0.0 & 0.0 & 0.0 \\
Mining & 0.0 & 0.0 & 0.7 \\
\hline Food & 100.0 & 100.0 & 100.0 \\
Beverages & 0.0 & 3.3 & 10.5 \\
Tobacco products & 0.0 & 7.7 & 14.4 \\
Textiles and leather & 0.0 & 2.7 & 15.8 \\
Wood & 0.0 & 0.0 & 0.0 \\
Paper & 0.0 & 0.0 & 0.0 \\
Refined petroleum products & 0.0 & 0.0 & 8.7 \\
Chemical products & 0.0 & 0.0 & 0.0 \\
Rubber and plastic & 0.0 & 0.0 & 0.0 \\
Non-metalic mineral products & 0.0 & 0.0 & 10.2 \\
Metal products & 0.0 & 0.0 & 7.3 \\
Machinery and vehicles & 0.0 & 0.0 & 0.0 \\
Other manufactures & 0.0 & 0.0 & 3.3 \\
\hline Electricity and gas & 0.0 & 0.0 & 0.7 \\
Construction & 0.0 & 0.0 & 0.0 \\
Trade, hotels and resturants & 0.0 & 0.0 & 0.0 \\
Transport & 0.0 & 0.0 & 4.3 \\
Communications & 0.0 & 0.0 & 0.0 \\
Government & 0.0 & 0.0 & 0.0 \\
Other services & 0.0 & 0.0 & 0.0 \\
\hline 'caculats & & &
\end{tabular}

Source: Authors' calculations. 
Journal of Global Economic Analysis, Volume 2 (2017), No. 1, pp. 120-165.

Table 8. Real output by sector (percent change from base).

\begin{tabular}{lrrrrr}
\hline Activity & base & low & medium & high & perfect \\
\hline Agriculture & 8,428 & -0.26 & -0.30 & -0.01 & 0.53 \\
Forestry & 1,568 & 0.02 & 0.11 & 0.22 & 0.43 \\
Fishing & 439 & 0.00 & 0.00 & 0.00 & -0.27 \\
\hline Petroleum and gas & 37 & 0.00 & 0.00 & -0.18 & -1.64 \\
Mining & 392 & 0.00 & 0.00 & -0.20 & -1.13 \\
\hline Food & 2,460 & 8.39 & 12.49 & 15.15 & 18.23 \\
Beverages & 308 & 0.00 & -0.77 & -2.51 & -3.92 \\
Tobbaco products & 21 & 0.00 & -5.17 & -9.71 & -13.08 \\
Textiles and leather & 333 & 0.00 & -1.06 & -6.55 & -10.67 \\
Wood & 7 & -2.97 & -3.46 & -3.31 & -2.79 \\
Paper & 26 & 0.00 & -1.03 & -4.14 & -6.93 \\
Refined petroleum products & 13 & 0.00 & 0.00 & -0.84 & -2.70 \\
Chemical products & 363 & 0.00 & 0.00 & -0.31 & -3.08 \\
Rubber and plastic & 63 & 0.00 & 0.00 & -1.41 & -3.61 \\
Non-metalic mineral products & 267 & 0.00 & -0.01 & -1.84 & -3.64 \\
Metal products & 265 & 0.00 & -0.38 & -1.94 & -4.36 \\
Machinery and vehicles & 49 & 0.00 & 0.00 & -1.72 & -4.29 \\
Other manufactures & 207 & 0.00 & 0.00 & -1.00 & -4.23 \\
\hline Electricity and gas & 181 & 0.00 & 0.00 & -0.31 & -2.70 \\
Construction & 2,256 & 0.06 & 0.09 & 0.10 & 0.12 \\
\hline Trade, hotels and resturants & 5,119 & 0.00 & 0.00 & 0.00 & 0.43 \\
Transport & 847 & 0.00 & 0.00 & -2.11 & -4.96 \\
Communications & 1,284 & 0.00 & 0.14 & 0.00 & -0.79 \\
Government & 1,216 & 0.00 & 0.00 & -1.40 & -6.07 \\
Other services & 8,180 & 0.00 & 0.05 & 0.49 & 0.72 \\
\hline Not: Fo th & & 0.00 &
\end{tabular}

Note: * For the zero mobility scenario, real output does no change from the base year.

Source: Authors' calculations. 
Journal of Global Economic Analysis, Volume 2 (2017), No. 1, pp. 120-165.

Table 9. Employment by sector in physical and efficiency units (percent change from base).

\begin{tabular}{|c|c|c|c|c|c|c|c|c|}
\hline \multirow[b]{2}{*}{ Activity } & \multicolumn{4}{|c|}{ Physical units } & \multicolumn{4}{|c|}{ Efficiency units } \\
\hline & low & medium & high & perfect & low & medium & high & perfect \\
\hline Agriculture & -0.36 & -0.41 & -0.01 & 0.72 & -0.36 & -0.41 & -0.01 & 0.72 \\
\hline Forestry & 0.10 & 0.37 & 0.71 & 1.22 & 0.06 & 0.30 & 0.62 & 1.22 \\
\hline Fishing & 0.00 & 0.00 & 0.00 & -1.27 & 0.00 & 0.00 & 0.00 & -1.27 \\
\hline Petroleum and gas & 0.00 & 0.00 & -0.64 & -5.54 & 0.00 & 0.00 & -0.64 & -5.54 \\
\hline Mining & 0.00 & 0.00 & -0.72 & -3.89 & 0.00 & 0.00 & -0.72 & -3.89 \\
\hline Food & 15.47 & 21.19 & 25.86 & 27.38 & 12.38 & 18.56 & 22.63 & 27.38 \\
\hline Beverages & 0.00 & -3.30 & -10.52 & -16.09 & 0.00 & -3.30 & -10.52 & -16.09 \\
\hline Tobacco products & 0.00 & -7.72 & -14.36 & -19.19 & 0.00 & -7.72 & -14.36 & -19.19 \\
\hline Textiles and leather & 0.00 & -2.67 & -15.83 & -25.04 & 0.00 & -2.67 & -15.83 & -25.04 \\
\hline Wood & -18.85 & -21.69 & -20.81 & -17.76 & -18.85 & -21.69 & -20.81 & -17.76 \\
\hline Paper & 0.00 & -3.75 & -14.48 & -23.41 & 0.00 & -3.75 & -14.48 & -23.41 \\
\hline Refined petroleum products & 0.00 & 0.00 & -8.67 & -25.82 & 0.00 & 0.00 & -8.67 & -25.82 \\
\hline Chemical products & 0.00 & 0.00 & -1.59 & -15.18 & 0.00 & 0.00 & -1.59 & -15.18 \\
\hline Rubber and plastic & 0.00 & 0.00 & -7.76 & -19.00 & 0.00 & 0.00 & -7.76 & -19.00 \\
\hline Non-metalic mineral products & 0.00 & -0.04 & -10.16 & -19.35 & 0.00 & -0.04 & -10.16 & -19.35 \\
\hline Metal products & 0.00 & -2.12 & -10.40 & -22.28 & 0.00 & -2.12 & -10.40 & -22.28 \\
\hline Machinery and vehicles & 0.00 & 0.00 & -10.88 & -25.53 & 0.00 & 0.00 & -10.88 & -25.53 \\
\hline Other manufactures & 0.00 & 0.00 & -3.29 & -13.49 & 0.00 & 0.00 & -3.29 & -13.49 \\
\hline Electricity and gas & 0.00 & 0.00 & -0.74 & -6.40 & 0.00 & 0.00 & -0.74 & -6.40 \\
\hline Construction & 0.27 & 0.23 & 0.23 & 0.24 & 0.12 & 0.18 & 0.20 & 0.24 \\
\hline Trade, hotels and resturants & 0.00 & 0.00 & 0.01 & 0.86 & 0.00 & 0.00 & 0.01 & 0.86 \\
\hline Transport & 0.00 & 0.00 & -4.29 & -9.93 & 0.00 & 0.00 & -4.29 & -9.93 \\
\hline Communications & 0.00 & 0.96 & 0.00 & -3.99 & 0.00 & 0.72 & 0.00 & -3.99 \\
\hline Government & 0.00 & 0.00 & -1.40 & -6.07 & 0.00 & 0.00 & -1.40 & -6.07 \\
\hline Other services & 0.00 & 0.11 & 1.07 & 1.36 & 0.00 & 0.09 & 0.94 & 1.36 \\
\hline
\end{tabular}

Source: Authors' calculations. 


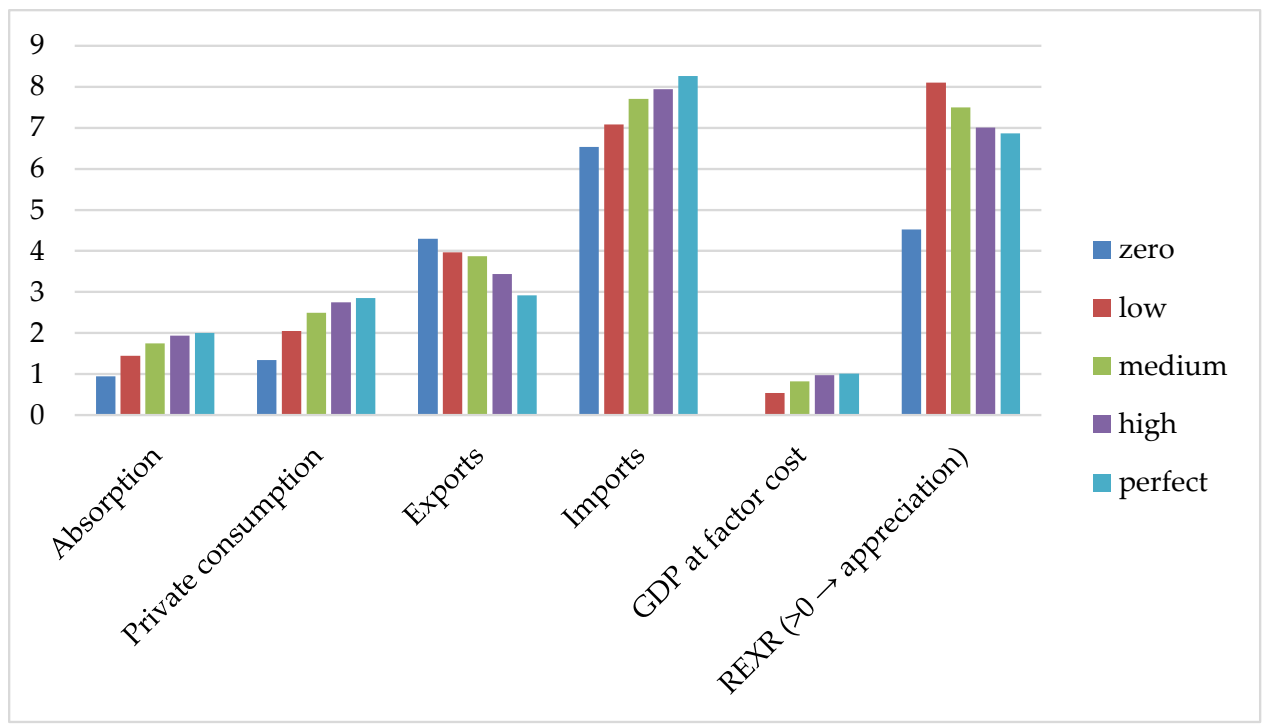

Figure 1. Real macro indicators by scenario (percent change from base).

Note: In this figure the definition of the real exchange rate was changed so that an increase means an appreciation.

Source: Authors' calculations.

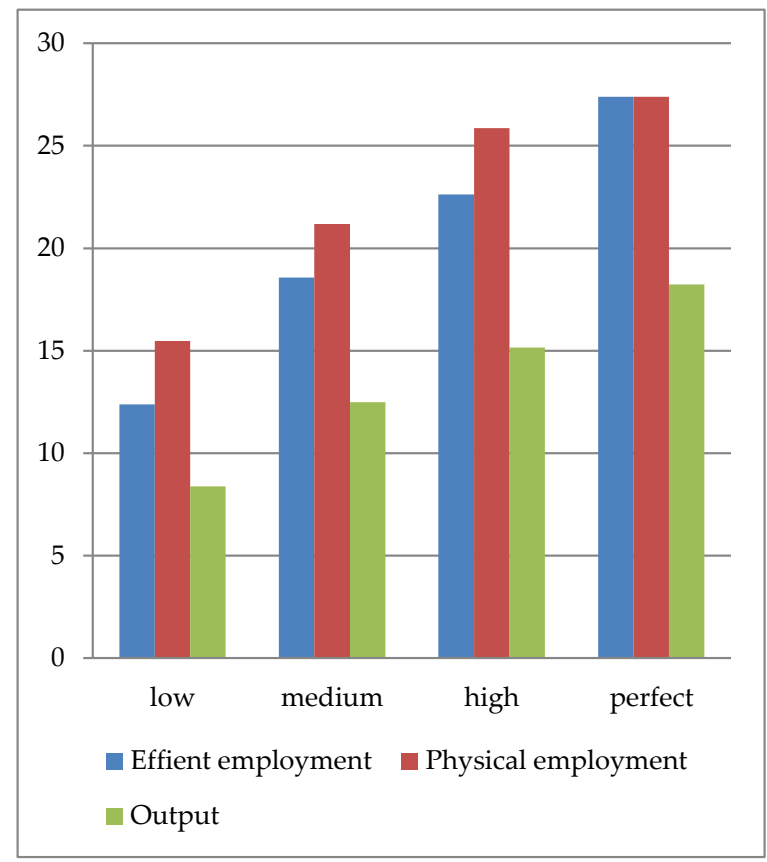

Figure 2. Employment and real output in food processing (percent change from base). Source: Authors' calculations. 


\section{Conclusions}

In this paper, we present an intuitive entry point to the modeling of labormarket mobility: labor movements and wage differentiation are driven by the extent to which sectors are similar in terms of the capabilities that are required from their workers. It fits naturally in economy-wide models where producer decisions are driven by profit-maximization and labor may be reallocated across sectors. The approach is flexible in that, subject to data constraints, it can replicate any observed pattern of pair-wise sector segmentation, including asymmetric patterns: for example, unskilled worker reallocation from agriculture to construction may be easy whereas reallocation in the opposite direction may be difficult due to the fact that construction workers lack many of the capabilities required in agricultural work.

A research agenda that draws on the proposed approach may address several issues. The top priority may be to empirically estimate proximity parameters, preferably with disaggregations that are closely aligned with the disaggregation of the rest of the application database both with regard to sectors and labor types. Given that mobility is likely to vary across labor types, the payoffs may be high from further disaggregation (for example on the basis of educational attainment or gender). Household and labor market surveys may provide (or be designed to provide) needed data on worker movements and how the wages received by workers employed in a sector differ depending on their sector of origin.

A second direction of research is related to extensions of the approach, each of which would come with its own additional data requirements. Here, top empirical priorities may be to bring unemployment into the model, presumably with sectoral capabilities assigned to the unemployed, and to make the analysis dynamic. In a dynamic setting, it would be necessary to model the evolution of the size of the labor pools, disaggregated by sector and perhaps according to other criteria. In light of learning by doing, it would be natural to expect the labor stocks (classified by assigned capabilities) to grow relatively fast for sectors with increasing shares of employment. It would also be necessary to consider the sectoral capabilities of those who enter to or exit from the labor force. ${ }^{26}$ When addressing these issues, it would be crucial to draw on the labor economics literature. The development of dynamic approaches to labor market modeling that

26 Those who enter and leave the labor force may be split into different categories. For example, entrants may be composed of people leaving school, immigrants, and youth reaching labor force age) while those who exit may be made up of those who leave the labor force due to emigration, retirement, and death. Movements into or out of the labor force may also be due to other causes (such as changing gender roles or changing prospects for landing a job). 
are policy relevant and both empirically valid and tractable is clearly a major task ahead for CGE modeling. ${ }^{27}$

\section{Acknowledgements}

The authors are grateful for financial support from the Knowledge for Change Program (KCP) of the World Bank. They also thank three anonymous referees for their very helpful comments.

\section{References}

Acemoglu, Daron, and David Autor. 2011. "Skills, Tasks and Technologies: Implications for Employment and Earnings," In Handbook of Labor Economics. Volume 4b, edited by Ashenfelter, Orley, and David Card. Amsterdam: North Holland, Elsevier B.V., 1043-1171.

Annabi, Nabil. 2003. "Modeling Labor Markets in CGE Models: Endogenous Labor Supply, Unions and Efficiency Wages." Working Paper. Poverty and Economic Policy (PEP), Université Laval, Quebec.

Armington, Paul. 1969. “A Theory of Demand for Products Distinguished by Place of Production." IMF Staff Papers 16: 159-176.

Boccanfuso, Dorothe, and Luc Savard. 2007 "Poverty and Inequality Impact Analysis Regarding Cotton Subsidies: A Mali-based CGE Micro-accounting Approach," Journal of African Economies, 16 (4): 629-659

Boeters, Stefan, and Luc Savard. 2013. "The Labor Market in Computable General Equilibrium Models," In Handbook of Computable General Equilibrium Modeling. Volume 1A, edited by Dixon, Peter B. and Dale W. Jorgenson. Amsterdam: North Holland, Elsevier B.V., 1645-1718.

Cooper, Russell, and Jonathan L. Willis. 2009. "The cost of labor adjustment: Inferences from the gap," Review of Economic Dynamics, 12 (4): 632-647.

Cooper, Russell, John Haltiwanger, and Jonathan L. Willis. 2015. "Dynamics of labor demand: Evidence from plant-level observations and aggregate implications," Research in Economics, 69 (1):37-50.Dervis, Kemal, Jaime de Melo, and Sherman Robinson. 1982. General Equilibrium Models for Development Policy. New York: Cambridge University Press.

Diao, Xinshen, and James Thurlow. 2012. "A Recursive Dynamic Computable General Equilibrium Model," In Strategies and Priorities for African Agriculture: Economywide Perspectives from Country Studies, edited by Diao, Xinshen, James

27 In dynamic settings, it may be possible to draw on entropy econometrics for the estimation of selected parameters, considering for example the impact of proximity values on the ability of a model to replicate historical changes in labor allocation; cf. Go et al. (2016). 
Thurlow, Samuel Benin, and Shenggen Fan. International Food Policy Research Institute, Washington, DC.

Erero, Jean Luc. 2016. "National minimum wage in South Africa: A Computable General Equilibrium Model Analysis," Economic Research Southern Africa (ERSA) working paper 650, November.

Flaig, Dorothee. 2014. Factor Mobility and Heterogeneous Labour in Computable General Equilibrium Modelling. Dissertation submitted in fulfilment of the requirements for the degree 'Doktor der Agrarwissenschaften'. Faculty of Agricultural Sciences. University of Hohenheim.

Gass, Saul I., and Arjang A. Assad. 2005. An Annotated Timeline of Operations Research: An Informal History. Boston: Kluwer Academic Publishers.

Go, Delfin S., Hans Lofgren, Fabian Mendez Ramos, and Sherman Robinson. 2016. "Estimating Parameters and Structural Change in CGE Models Using a Bayesian Cross-Entropy Estimation Approach," Economic Modelling 52 (Part B): 790-811.

Go, Delfin S., Marna Kearney, Vijdan Korman, Sherman Robinson, and Karen Thierfelder. 2010. "Wage Subsidy and Labour Market Flexibility in South Africa," Journal of Development Studies, 46 (9): 1481-1502.

Hamermesh, Daniel S. 1989. "Labor demand and the structure of adjustment costs," American Economic Review, 79 (4): 674-689.

Hausmann, Ricardo, and Bailey Klinger. 2006. "Structural transformation and patterns of comparative advantage in the product space," CID working paper Vol. no. 128, Center for International Development at Harvard University, Cambridge, MA.

Hausmann, Ricardo, César A. Hidalgo, Sebastián Bustos, Michele Coscia, Sarah Chung, Juan Jimenez, Alexander Simoes, and Muhammed A. Yıldırım. 2011. The Atlas of Economic Complexity: Mapping Paths to Prosperity. Center for International Development, John F. and Kennedy School of Government. Cambridge, MA: Harvard University; and Macro Connections Media Lab. Cambridge, MA: Massachusetts Institute of Technology. (http://atlas.media.mit.edu/static/pdf/atlas/AtlasOfEconomicComplexity.p df)

Hertel, Thomas W., and Marinos E. Tsigas. 1997. "Structure of GTAP." In Global Trade Analysis: Modeling and Applications, edited by Hertel, Thomas W. New York: Cambridge University Press, 13-63.

Hertel, Thomas W., and Jeffrey J. Reimer. 2005. "Predicting the Poverty Impacts of Trade Reform," Journal of International Trade and Economic Development, 14 (4): 377-405.

Hidalgo, César A., Bailey Klinger, Albert-László Barabási, and Ricardo Hausmann. 2007. "The product space conditions the development of nations," Science 317 (5837): 482-487. 
Lewis, W. Arthur. 1954. "Economic Development with Unlimited Supplies of Labor," The Manchester School 22, 139-191.

Lindbeck, Assar, and Dennis J. Snower. 1988. The Insider-Outside Theory of Employment and Unemployment. Cambridge, MA: MIT Press.

Lofgren, Hans, Rebecca Lee Harris, and Sherman Robinson, with assistance from Moataz El-Said and Marcelle Thomas. 2002. A Standard Computable General Equilibrium (CGE) Model in GAMS. Microcomputers in Policy Research, Vol. 5. Washington, D.C.: IFPRI.

Maechler, Andréa, and David W. Roland-Holst. 1997. "Labor Market Structure and Conduct." In Applied Methods for Trade Policy Analysis: A Handbook, edited by Francois, Joseph F., and Kenneth A. Reinert New York, NY: Cambridge University Press, 479-516.

Marshall, Alfred. 1920. Principles of Economics. 8th edition. London: Macmillan and Co.

Narayanan, G., Badri, Angel Aguiar, and Robert McDougall, eds. 2012. "Global Trade, Assistance, and Production: The GTAP 8 Data Base," Center for Global Trade Analysis, Purdue University, West Lafayette, IN.

Pauw, Karl, and Murray Leibbrandt. 2012. "Minimum wages and household poverty: general equilibrium macro-micro simulations for South Africa," World Development 40 (4): 771-783.

Porto, Guido, and Bernard Hoekman. 2010. "Trade Adjustment Costs in Developing Countries: Impacts, Determinants and Policy Responses." In Trade Adjustment Costs in Developing Countries: Impacts, Determinants and Policy Responses, edited by Porto, Guido, and Bernard Hoekman. Washington, DC: World Bank, 1-24.

Seale, James Jr., Anita Regmi, and Jason Bernstein. 2003. "International Evidence on Food Consumption Patterns," United States Department of Agriculture Technical Bulletin 1904, Washington, DC.

Thierfelder, Karen, and Clinton R. Shiells. 1997. "Trade and Labor Market Behavior." In Applied Methods for Trade Policy Analysis: A Handbook, edited by Francois, Joseph F., and Kenneth A. Reinert. New York, NY: Cambridge University Press, 435-478.

Thompson, Gerald L., and Sten Thore. 1992. Computational Economics: Economic Modeling with Optimization Software. San Francisco, CA: Scientific Press.

United Nations. 2003. "National Accounts: A Practical Introduction," Department of Economic and Social Affairs Statistics Division. Studies in Methods. Handbook of National Accounting. Series F, No.85, New York, NY.

United Nations. 2015. "UN Comtrade Database," United Nations, New York, NY. van der Mensbrugghe, Dominique. 2007. "Modeling the Impact of Trade Liberalization: A Structuralist Perspective?" Paper presented at the 10th Annual Conference on Global Economic Analysis, held at Purdue University, June 7-9, 2007. 
Weiss, Andrew. 1991. Efficiency Wage: Models of Unemployment, Layoffs, and Wage Dispersion. Princeton University Press.

World Bank. 2016. World Development Indicators 2016. Washington, DC: World Bank.

\section{Appendix. Mathematical statement of CGE model}

This appendix provides a detailed mathematical statement of the CGE model used for this paper. The model equations are divided into four blocks: A. Production activities and factor markets; B. Domestic and foreign trade; C. Domestic institutions; and D. System constraints and price indices.

Tables A.1-A.5 explain notational principles and define model sets, variables, and parameters. Drawing on these tables and set of tables with the model equations (Tables A.6-A.9), we subsequently provide a detailed presentation of the model equations with one section for each block. In the mathematical presentation, the settings for closure rules (for government budget, savings-investment payments, and factor and commodity markets) and other assumptions match what was used in the simulations of this paper.

Table A.1. Notational principles.

\begin{tabular}{|l|l|c|}
\hline Items & Notation & Example \\
\hline Sets & $\begin{array}{l}\text { Lower-case Latin letters as subscripts to variables } \\
\text { and parameters }\end{array}$ & $\begin{array}{l}\text { exemplified on the } \\
\text { following rows }\end{array}$ \\
\hline $\begin{array}{l}\text { Endogenous } \\
\text { variables }\end{array}$ & Upper-case Latin letters (without a bar)* & $Q G_{c}$ \\
\hline $\begin{array}{l}\text { Exogenous } \\
\text { variables }\end{array}$ & Upper-case Latin letters with a bar* & $\overline{Q F S}$ \\
\hline Parameters & $\begin{array}{l}\text { Lower-case Latin letters* or lower-case Greek } \\
\text { letters (with or without superscripts) }\end{array}$ & $i c a_{c, a} ; \rho_{c}^{q}$ \\
\hline
\end{tabular}

Note: * The names of Latin letter variables and parameters that refer to prices, quantities, and wages (rents) start with $P, Q$, and $W F$, respectively.

Table A.2. Sets.

\begin{tabular}{|c|l|}
\hline Name & Description \\
\hline$a \in A$ & activities (production sectors or industries) \\
\hline$c \in C$ & commodities (i.e., goods and services) \\
\hline$c \in C D(\subset C)$ & commodities with domestic sales of domestic output \\
\hline$c \in C E(\subset C)$ & exported commodities \\
\hline$c \in C M(\subset C)$ & imported commodities \\
\hline$c \in C T(\subset C)$ & $\begin{array}{l}\text { transactions commodities (trade and transport services paid for } \\
\text { under distribution margins) }\end{array}$ \\
\hline$f \in F$ & factors \\
\hline
\end{tabular}


Journal of Global Economic Analysis, Volume 2 (2017), No. 1, pp. 120-165.

\begin{tabular}{|c|l|}
\hline$f \in F N P R O X(\subset F)$ & factors without proximity-based sectoral allocation \\
\hline$f \in F P R O X(\subset F)$ & factors with proximity-based sectoral allocation \\
\hline$i \in I N S$ & institutions \\
\hline$i \in I N S D(\subset I N S)$ & domestic institutions \\
\hline$i \in I N S D N G(\subset I N S D)$ & domestic non-government institutions \\
\hline$h \in H(\subset I N S D N G)$ & households \\
\hline
\end{tabular}


Table A.3. Variables.

\begin{tabular}{|c|c|}
\hline Name & Description \\
\hline$C P I$ & consumer price index \\
\hline DPI & domestic producer price index (PDS-based) \\
\hline$E G$ & total current government expenditure \\
\hline$E H_{h}$ & household consumption expenditure \\
\hline EXR & exchange rate (local currency per unit of foreign currency \\
\hline$M P S_{i}$ & marginal propensity to save for domestic non-government institutions $i$ (in INSDNG) \\
\hline MPSSCAL & MPS scaling factor \\
\hline$P A_{a}$ & output price of activity $a$ \\
\hline$P D D_{c}$ & demand price for commodity $c$ produced and sold domestically \\
\hline$P D S_{c}$ & supply price for commodity c produced and sold domestically \\
\hline$P E_{c}$ & export price for $c$ (domestic currency) \\
\hline$P M_{c}$ & import price for $c$ (domestic currency) \\
\hline$P Q_{c}$ & composite commodity price for $c$ \\
\hline$P X_{c}$ & producer price for commodity $c$ \\
\hline$Q A_{a}$ & level of activity $a$ \\
\hline$Q D_{c}$ & quantity sold domestically of domestic output $c$ \\
\hline$Q E_{c}$ & quantity of exports of commodity $c$ \\
\hline$Q F_{f, a}$ & quantity demanded of factor $f$ by activity $a$ \\
\hline$Q F A A_{f, a, a^{\prime}}$ & quantity of factor $f$ in $a$ allocated to $a^{\prime}$ ( $f$ in FPROX) \\
\hline$Q F A S_{f, a}$ & quantity supplied of factor $f$ in activity $a$ \\
\hline$Q F S_{f}$ & supply of factor $f$ (in FNPROX) \\
\hline$Q F_{c}$ & quantity of government consumption of commodity $c$ \\
\hline$Q G S C A L$ & government consumption scaling factor \\
\hline$Q H_{c, h}$ & quantity consumed of commodity $c$ by household $h$ \\
\hline$Q I N T_{c, a}$ & quantity of commodity $c$ as intermediate input to activity $a$ \\
\hline$Q I N V_{c}$ & quantity of investment demand for commodity $c$ \\
\hline QINVSCAL & investment scaling factor \\
\hline$Q M_{c}$ & quantity of imports of commodity $c$ \\
\hline$Q Q_{c}$ & quantity of composite supply and demand of commodity $c$ \\
\hline$Q T_{c}$ & quantity of transactions demand for commodity $c$ \\
\hline$Q X_{c}$ & quantity of domestic output of commodity $c$ \\
\hline$R S A V G$ & real government savings (CPI-indexed) \\
\hline$S A V F$ & foreign savings (FCU) \\
\hline$S A V G$ & government savings \\
\hline SAVINS $_{i}$ & savings of domestic non-government institution $i$ (in INSDNG) \\
\hline$T R I I_{i^{\prime}, i}$ & $\begin{array}{l}\text { transfers to institution } i \text { (in INS) from domestic non-government institution } i^{\prime} \text { (in } \\
\text { INSDNG) }\end{array}$ \\
\hline$T Y_{i}$ & rate of direct tax on domestic non-government institution $i$ (in INSDNG) \\
\hline TYSCAL & scaling variable for direct tax on domestic non-government institutions \\
\hline WALRAS & variable checking satisfaction of Walras' law \\
\hline$W F_{f}$ & economy-wide wage of factor $f$ (in FNPROX) \\
\hline
\end{tabular}


Journal of Global Economic Analysis, Volume 2 (2017), No. 1, pp. 120-165.

\begin{tabular}{|c|l|}
\hline$W F A D_{f, a}$ & $\begin{array}{l}\text { wage per efficiency unit of } f \text { in destination activity } a \text { (before WFDIST adjustment; } f \text { in } \\
\text { FPROX) }\end{array}$ \\
\hline$W F A S_{f, a}$ & $\begin{array}{l}\text { wage per physical and efficiency unit of } f \text { in source activity } a \text { (before WFDIST } \\
\text { adjustment; } f \text { in } F P R O X)\end{array}$ \\
\hline$W F D I S T_{f, a}$ & wage distortion factor for factor $f$ in activity $a$ \\
\hline$Y F_{f}$ & income of factor $f$ \\
\hline$Y G$ & government current revenue \\
\hline$Y I_{i}$ & income of (domestic non-government) institution $i$ (in INSDNG) \\
\hline$Y I F_{i, f}$ & income of institution $i$ (in INS) from factor $f$ \\
\hline
\end{tabular}


Table A.4. Latin letter parameters.

\begin{tabular}{|c|l|}
\hline Name & Description \\
\hline$c w t s_{c}$ & weight of commodity $c$ in the CPI \\
\hline$d w t s_{c}$ & weight of commodity $c$ in the DPI \\
\hline$i c a_{c, a}$ & quantity of intermediate input c per unit of activity $a$ \\
\hline$i c d_{c, c^{\prime}}$ & transactions input of $c$ per unit of commodity $c^{\prime}$ produced and sold domestically \\
\hline$i c e_{c, c^{\prime}}$ & transactions input of $c$ per unit of commodity $c^{\prime}$ that is exported \\
\hline$i c m_{c, c^{\prime}}$ & transactions input of $c$ per unit of commodity $c^{\prime}$ that is imported \\
\hline$m p s b_{i}$ & $\begin{array}{l}\text { base-year marginal propensity to save for domestic non-government institution } i \text { (in } \\
\text { INSDNG) }\end{array}$ \\
\hline$p r o x f_{f, a, a^{\prime}}$ & proximity to activity $a^{\prime}$ for factor $f$ in activity $a$ \\
\hline$p w e_{c}$ & export price for $c$ (foreign currency) \\
\hline$p w m_{c}$ & import price for $c$ (foreign currency) \\
\hline$q d s t k_{c}$ & change in stock (inventories) of $c$ \\
\hline$q g b c_{c}$ & base-year quantity of government consumption of commodity $c$ \\
\hline$q i n v b_{c}$ & base-year quantity of investment (GFCF) demand for $c$ \\
\hline$s h i f_{i, f}$ & share for institution $i$ (in INS) in the income of factor $f$ \\
\hline$s h i i_{i^{\prime}, i}$ & $\begin{array}{l}\text { share of institution } i^{\prime} \text { (in INS) in the disposable income of domestic non-government } \\
\text { institution } i \text { (in INSDNG) }\end{array}$ \\
\hline$t r n s f r_{a c, i}$ & $\begin{array}{l}\text { transfers from institution i (government or rest of world) to institution } i \text { (in INS) or factor } f \\
\text { (in } F \text { ) }\end{array}$ \\
\hline$t a_{a}$ & rate of tax on gross output value for activity $a$ \\
\hline$t e_{c}$ & rate of export tax on commodity $c$ \\
\hline$t f_{f}$ & rate of direct tax on factor $f$ \\
\hline$t m_{c}$ & rate of import tariff on commodity $c$ \\
\hline$t q_{c}$ & rate of sales tax on commodity $c$ \\
\hline$t y b_{i}$ & base rate of direct tax on domestic non-government institution $i$ (in INSDNG) \\
\hline
\end{tabular}


Table A.5. Greek letter parameters.

\begin{tabular}{|c|l|}
\hline Name & Description \\
\hline$\beta_{c, h}$ & share parameter in LES function for household consumption of commodity $c$ \\
\hline$\gamma_{c, h}$ & subsistence quantity in LES function for household consumption of commodity $c$ \\
\hline$\delta_{c}^{d d}$ & share parameter for domestic purchases in Armington function for commodity $c$ \\
\hline$\delta_{c}^{d s}$ & share parameter for domestic sales in CET function for commodity $c$ \\
\hline$\delta_{c}^{e}$ & share parameter for exports in CET function for commodity $c$ \\
\hline$\delta_{c}^{m}$ & share parameter for imports in Armington function for commodity $c$ \\
\hline$\delta_{f, a}^{v a}$ & share parameter for factor $f$ in CES VA function of activity $a$ \\
\hline$\theta_{a, c}$ & yield of output c per unit of activity $a$ \\
\hline$\rho_{c}^{q}$ & exponent in Armington function for commodity $c$ \\
\hline$\rho_{a}^{v a}$ & exponent in CES VA function for activity $a$ \\
\hline$\rho_{c}^{x}$ & exponent in CET function for commodity $c$ \\
\hline$\sigma_{c}^{q}$ & $\begin{array}{l}\text { elasticity of substitution between purchases of domestic output and imports in Armington } \\
\text { function for } c\end{array}$ \\
\hline$\sigma_{a}^{v a}$ & elasticity of substitution between factors in CES VA function of activity $a$ \\
\hline$\sigma_{c}^{x}$ & elasticity of transformation between domestic sales and exports in CET function for $c$ \\
\hline$\varphi_{c}^{q}$ & shift parameter in Armington function for commodity $c$ \\
\hline$\varphi_{c}^{v a}$ & shift parameter for CES VA function of activity $a$ \\
\hline$\varphi_{c}^{x}$ & shift parameter in CET function for commodity $c$ \\
\hline & \\
\hline
\end{tabular}

Table A.6. Equations for production activities and factor markets.

\begin{tabular}{l|c|c|l}
\hline PRD1 & $Q A_{a}=\varphi_{a}^{v a}\left(\sum_{f} \delta_{f, a}^{v a} \cdot Q F_{f, a}^{-\rho_{a}^{v a}}\right)^{\frac{-1}{\rho_{a}^{v a}}}$ & $a \in A$ & $\begin{array}{l}\text { Value- } \\
\text { added }\end{array}$ \\
\hline PRD2 & $\overline{Q F}_{f, a}=\left(\frac{P V A_{a}}{\overline{W F}_{f} \cdot W F D I S T_{f, a}}\right)^{\sigma_{a}^{v a}}\left(\delta_{f, a}^{v a}\right)^{\sigma_{a}^{v a}}\left(\varphi_{a}^{v a}\right)^{\sigma_{a}^{v a}-1} \cdot Q A_{a}$ & $\begin{array}{c}f \in F N P R O X \\
a \in A\end{array}$ & $\begin{array}{l}\text { Factor } \\
\text { demands } \\
\text { (non- } \\
\text { proximity) }\end{array}$ \\
\hline PRD3 & $Q F_{f, a}=\left(\frac{P V A_{a}}{W F A D_{f, a}}\right)^{\sigma_{a}^{v a}}\left(\delta_{f, a}^{v a}\right)^{\sigma_{a}^{v a}}\left(\varphi_{a}^{v a}\right)^{\sigma_{a}^{v a}-1} \cdot Q A_{a}$ & $\begin{array}{c}f \in F N P R O X \\
a \in A\end{array}$ & $\begin{array}{l}\text { Factor } \\
\text { demands } \\
\text { (proximity) }\end{array}$ \\
\hline PRD4 & $Q I N T_{c, a}=i c a_{c, a} \cdot Q A_{a}$ & $\begin{array}{l}c \in C \\
a \in A\end{array}$ & $\begin{array}{l}\text { Intermedi- } \\
\text { ate } \\
\text { demands }\end{array}$ \\
\hline PRD5 & $Q X_{c}=\sum_{a \in A} \theta_{a, c} \cdot Q A_{a}$ & $c \in C$ & Output \\
\hline
\end{tabular}




\begin{tabular}{|c|c|c|c|}
\hline PRD6 & $P V A_{a}=P A_{a}\left(1-t a_{a}\right)-\sum_{c \in C} P Q_{c} \cdot i c a_{c, a}$ & $a \in A$ & $\begin{array}{l}\text { Value- } \\
\text { added price }\end{array}$ \\
\hline PRD7 & $P A_{a}=\sum_{c \in C} \theta_{a, c} \cdot P X_{c}$ & $a \in A$ & $\begin{array}{l}\text { Activity } \\
\text { price }\end{array}$ \\
\hline PRD8 & $Q F S_{f}=\sum_{a \in A} \overline{Q F}_{f, a}$ & $f \in F N P R O X$ & $\begin{array}{l}\text { Factor } \\
\text { markets } \\
\text { (non- } \\
\text { proximity) }\end{array}$ \\
\hline PRD9 & $\overline{Q F A S}_{f, a}=\sum_{a^{\prime}} Q F A A_{f, a, a^{\prime}}$ & $\begin{array}{c}f \in F P R O X \\
a \in A\end{array}$ & $\begin{array}{l}\text { Factor } \\
\text { markets } \\
\text { (proximity) }\end{array}$ \\
\hline PRD10 & $\sum_{a \in A} \operatorname{proxf}_{f, a, a^{\prime}} \cdot Q F A A_{f, a, a^{\prime}}=Q F_{f, a^{\prime}}$ & $\begin{array}{c}f \in F P R O X \\
a^{\prime} \in A\end{array}$ & $\begin{array}{l}\text { Efficient } \\
\text { employmen } \\
t \\
\text { (proximity) }\end{array}$ \\
\hline PRD11 & $W F A S_{f, a} \geq W F A D_{f, a^{\prime}} \cdot \operatorname{proxf}_{f, a, a^{\prime}}$ & $\begin{array}{c}f \in F P R O X \\
a \in A \\
a^{\prime} \in A \\
\end{array}$ & $\begin{array}{l}\text { Source- } \\
\text { destination } \\
\text { wage } \\
\text { constraint } \\
\text { (proximity) }\end{array}$ \\
\hline PRD12 & $Q F A A_{f, a, a^{\prime}} \geq 0$ & $\begin{array}{c}f \in F P R O X \\
a \in A \\
a^{\prime} \in A\end{array}$ & $\begin{array}{l}\text { Factor } \\
\text { allocation } \\
\text { constraint } \\
\text { (proximity) }\end{array}$ \\
\hline PRD13 & $\left(W F A S_{f, a}-W F A D_{f, a^{\prime}} \cdot \operatorname{proxf}_{f, a, a^{\prime}}\right) Q F A A_{f, a, a^{\prime}}$ & $\begin{array}{c}f \in F P R O X \\
a \in A \\
a^{\prime} \in A\end{array}$ & $\begin{array}{l}\text { Mixed- } \\
\text { comple- } \\
\text { mentarity } \\
\text { constraint } \\
\text { (proximity) }\end{array}$ \\
\hline PRD14 & $Y F_{f}=\sum_{a \in A} \overline{W F}_{f} \cdot W F D I S T_{f, a} \cdot \overline{Q F}_{f, a}+\operatorname{trnsfr}_{f, \text { row }} \cdot E X R$ & $f \in$ FNPROX & $\begin{array}{l}\text { Factor } \\
\text { income } \\
\text { (non- } \\
\text { proximity) }\end{array}$ \\
\hline PRD15 & $\begin{array}{c}Y F_{f}=\sum_{a \in A} W F A D_{f, a} \cdot W F D I S T_{f, a} \cdot Q F_{f, a}+t r n s f r_{f, r o w} \\
\cdot E X R\end{array}$ & $f \in F P R O X$ & $\begin{array}{l}\text { Factor } \\
\text { income } \\
\text { (proximity) }\end{array}$ \\
\hline
\end{tabular}

\section{Production activities and factor markets}

The equations for this block are presented in Table A.6. Equations PRD1-PRD3 are the first-order conditions for the optimization problem solved by the representative firm in each industry or activity (i.e., cost minimization/profit 
maximization). ${ }^{28}$ The value added production technology is CES (Constant Elasticity of Substitution; equation PRD1). In the demand functions for factors $f$ without the proximity treatment (in FNPROX; PRD2), the (unit) wage in activity a is computed as $W F_{f} \cdot W F D I S T_{f, a}$, where $W F D I S T_{f, a}$ is a "distortion" factor that allows modeling cases in which the factor remuneration differs across activities. ${ }^{29}$ As discussed in Lofgren et al.(2002), this formulation facilitates implementing alternative closures (i.e., mechanisms to equalize quantities supplied and demanded) in the factor markets. ${ }^{30}$ In this application, the factors in FNPROX are all activity-specific and $W F D I S T_{f, a}$ is the variable that clears these activity-specific markets.

For factors in FPROX; i.e., factors with proximity-based sectoral movements, the treatment is based on the optimization problem that was presented in Section 2.2. Equation PRD3 provides the demand functions for this factor subset. Given that factor supplies are exogenous by activity (as indicated by the bar on the factor employment variable $Q F A S_{f, a}$ ), their wage variables, $W F A S_{f, a}$, clear the markets. Equation PRD4 defines intermediate input demands using Leontief coefficients, which represent exogenous quantities of intermediate input by commodity and activity $\left(i c a_{c, a}\right)$.

Equation PRD5 computes the production of each commodity on the basis of the $\theta_{a, c}$ parameter, which is a fixed output coefficient (the production of $c$ per unit of activity $a$ ). Thus, like the supply-and-use tables, our model differentiates between activities and commodities (or products): an activity can produce more than commodity and the same commodity may be produced by more than one activity.

Equations PRD6 and PRD7 define prices related to each production activity. In equation PRD6, the price of value added (the payment to value added per unit of each activity) is defined as the difference between the activity price (the payment received for outputs per unit of the activity net of the tax on activity revenue) minus the cost of intermediate inputs per unit of the activity. The latter cost is the product of the above-mentioned intermediate input coefficient $\left(i c a_{c, a}\right)$ and the price of each intermediate, summed over all intermediates. Equation PRD7 defines the activity price as the product of output yields per unit of the activity, $\theta_{a, c}$, and related producer output prices, summed over all outputs.

The remaining equations of this block are factor-related, imposing equality between quantities demanded and supplied. As noted, in the current application, all factors in the set FNPROX are activity-specific with the variable clearing their

${ }_{28}$ To make it easier to read the equations, multiplication signs are inserted between multiplied items unless one or both are parenthesized.

${ }^{29}$ In this presentation, its value is exogenous only for labor, the only factor in FPROX (see below).

${ }^{30}$ Besides, for the factors considered as specific, equation (PRD3) is interpreted as an equilibrium condition between factor supply and demand. 
markets (cf. equation PRD2). Given this, the economy-wide market equilibrium condition, PRD8, becomes superfluous; here it simply defines total factor supply (which is endogenous) as the sum of the exogenous demands in the different activities. To facilitate a switch to closures where this condition matters, this equation is nevertheless retained. ${ }^{31}$

On the other hand, drawing on the optimization analysis in Section 2.2., for a factor $f$ in the set FPROX, equation PRD9 constrains total employment from source (or supply) activity a to the exogenous supply quantity. The related marketclearing variable, $W F A S_{f, a}$, is the wage per physical unit of factor $f$ from activity $a$. Equation PRD10 defines the efficient quantity of each factor $f$ employed in a destination activity a' as the sum of the efficiency-adjusted physical quantities of factor $f$ from different activities $a$; the related variable $W F A D_{f, a}$ represents the market-based wage per efficiency unit of factor $f$ in destination activity $a$. Equation PRD11 states that, for each factor $f$, the wage per physical unit in its source activity $a$ is at least as high as the wage per physical unit in destination activity $a^{\prime}$, with the latter defined as the proximity-scaled efficiency wage. Equation PRD12 imposes that the quantity of factor $f$ from source activity $a$ employed in destination activity $a^{\prime}$ is non-negative. The two equations are linked via equation PRD13, a mixedcomplementarity relationship, which states that two regimes are possible. In the first regime, $Q F A A_{f, a, a^{\prime}}>0$ (i.e., a positive quantity of factor $f$ moves from $a$ to $a^{\prime}$ ); in the current simulations, this is invariably the case for $a=a^{\prime}$ (at least part of the supply of each factor stays employed in its activity of origin) but typically also for some $a-a^{\prime}$ mappings with $a \neq a^{\prime}$. If $Q F A A_{f, a, a^{\prime}}>0$, then the parenthesized part of equation PRD13 must equal zero. In effect, $W F A S_{f, a}=W F A D_{f, a^{\prime}}$ when $a=a^{\prime}$ (i.e., for the part of the factor that stays in its activity of origin). If part of the supply in $a$ moves to another activity $a^{\prime}$ for some $f-a-a^{\prime}$ mappings with $\operatorname{proxf}_{f, a, a^{\prime}}<1$, then $W F A D_{f, a^{\prime}}>W F A S_{f, a}$, (i.e., in order for $a^{\prime}$ to pay the same wage per physical unit of $f$ as $a$ while maximizing its profits, the scarcity value per efficiency unit of $f$ in $a^{\prime}$ must exceed its value per physical and efficiency unit in $a$ ). The second regime applies to the $f-a-a^{\prime}$ mappings for which $Q F A A_{f, a, a^{\prime}}=0$; in our application, this is the most common case when $a \neq a^{\prime}$. If so, the parenthesized part of PRD13 may be a strict inequality, i.e. the efficiency wage of $f$ in $a^{\prime}$ is too low to make up for the efficiency loss (due to that $\operatorname{proxf}_{f, a, a^{\prime}}<1$ ).

In equations PRD14 and PRD15, the total income of each factor $f, Y F_{f}$, is defined for factors without and with proximity-based sectoral allocation, respectively. In

31 Different treatments are possible. For example, total supply (employment) may be exogenous while mobility may be free across all activities; for such factors, $Q F S_{f}$ and $W F D I S T_{f, a}$ would be exogenous while $Q F_{f, a}$ and $W F_{f}$ would be endogenous, leaving the total number of endogenous variables unchanged. In this case, equation PRD2 is an essential part of the model. 
both equations, the first term on the right hand side corresponds to the total factor payments from activities while the second term defines transfers to factors from the rest of the world. ${ }^{32}$

Table A.7. Equations for domestic and foreign trade.

\begin{tabular}{|c|c|c|c|}
\hline TRD1 & $P E_{c}=\left(1-t e_{c}\right) E X R \cdot p w e_{c}-\sum_{c^{\prime} \in C T} P Q_{c^{\prime}} \cdot i c e_{c^{\prime}, c}$ & $c \in C$ & $\begin{array}{l}\text { Export } \\
\text { price }\end{array}$ \\
\hline TRD2 & $P M_{c}=\left(1+t m_{c}\right) E X R \cdot p w m_{c}+\sum_{c^{\prime} \in C T} P Q_{c^{\prime}} \cdot i c m_{c^{\prime}, c}$ & $c \in C$ & $\begin{array}{l}\text { Import } \\
\text { price }\end{array}$ \\
\hline TRD3 & $P D D_{c}=P D S_{c}+\sum_{c^{\prime} \in C T} P Q_{c^{\prime}} \cdot i c d_{c^{\prime}, c}$ & $c \in C$ & $\begin{array}{l}\text { Domestic } \\
\text { demand- } \\
\text { er price }\end{array}$ \\
\hline TRD4 & $Q Q_{c}=\varphi_{c}^{q}\left(\delta_{c}^{m} \cdot Q M_{c}^{-\rho_{c}^{q}}+\delta_{c}^{d d} \cdot Q D_{c}^{-\rho_{c}^{q}}\right)^{\frac{-1}{\rho_{c}^{q}}}$ & $c \in C M \cap C D$ & $\begin{array}{l}\text { Com- } \\
\text { posite } \\
\text { supply } \\
\text { (trad- } \\
\text { ables) } \\
\end{array}$ \\
\hline TRD5 & $Q Q_{c}=Q M_{c}+Q D_{c}$ & $\begin{array}{l}(c \in C M \cap c \\
\notin C D) \\
\cup(c \in C D \cap c \\
\notin C M)\end{array}$ & $\begin{array}{l}\text { Com- } \\
\text { posite } \\
\text { supply } \\
\text { (non- } \\
\text { trad- } \\
\text { ables) }\end{array}$ \\
\hline TRD6 & $\frac{Q M_{c}}{Q D_{c}}=\left(\frac{P D D_{c}}{P M_{c}} \frac{\delta_{c}^{m}}{\delta_{c}^{d d}}\right)^{\frac{1}{1+\rho_{c}^{q}}}$ & $c \in C M \cap C D$ & $\begin{array}{l}\text { Import- } \\
\text { domestic } \\
\text { demand } \\
\text { ratio }\end{array}$ \\
\hline TRD7 & $P Q_{c} \cdot Q Q_{c}=\left(P M_{c} \cdot Q M_{c}+P D D_{c} \cdot Q D_{c}\right)\left(1+t q_{c}\right)$ & $c \in C$ & $\begin{array}{l}\text { Composi } \\
\text { te price }\end{array}$ \\
\hline TRD8 & $Q X_{c}=\varphi_{c}^{x}\left(\delta_{c}^{e} \cdot Q E_{c}^{\rho_{c}^{x}}+\delta_{c}^{d s} \cdot Q D_{c}^{-\rho_{c}^{x}}\right)^{\frac{-1}{\rho_{c}^{x}}}$ & $c \in C E \cap C D$ & $\begin{array}{l}\text { Output } \\
\text { transfor- } \\
\text { mation } \\
\text { (trad- } \\
\text { ables) }\end{array}$ \\
\hline TRD9 & $Q X_{c}=Q E_{c}+Q D_{c}$ & $\begin{array}{l}(c \in C E \cap c \\
\notin C D) \\
\cup(c \in C D \cap c \\
\notin C E)\end{array}$ & $\begin{array}{l}\text { Output } \\
\text { transfor- } \\
\text { mation } \\
\text { (non- } \\
\text { trad- } \\
\text { ables) }\end{array}$ \\
\hline
\end{tabular}

32 Note that the trnsfr parameter is in foreign currency units. 


\begin{tabular}{c|c|c|l}
\hline TRD10 & $\frac{Q E_{c}}{Q D_{c}}=\left(\frac{P E_{c}}{P D S_{c}} \frac{\delta_{c}^{d s}}{\delta_{c}^{e}}\right)^{\frac{1}{\rho_{c}^{x}-1}}$ & $c \in C E \cap C D$ & $\begin{array}{l}\text { Export- } \\
\text { domestic } \\
\text { demand } \\
\text { ratio }\end{array}$ \\
\hline TRD11 & $P X_{c} \cdot Q X_{c}=\left(P E_{c} \cdot Q E_{c}+P D S_{c} \cdot Q D_{c}\right)$ & $c \in C$ & $\begin{array}{l}\text { Producer } \\
\text { output } \\
\text { price }\end{array}$ \\
\hline TRD12 & $Q T_{c}=\sum_{c^{\prime} \in C} i c d_{c, c^{\prime}} \cdot Q D_{c^{\prime}}+\sum_{c^{\prime} \in C} i c m_{c, c^{\prime}} \cdot Q M_{c^{\prime}}+\sum_{c^{\prime} \in C} i c e_{c, c^{\prime}}$ & $c \in C T$ & $\begin{array}{l}\text { Trans- } \\
\text { actions } \\
\text { demand }\end{array}$ \\
\hline
\end{tabular}

\section{Domestic and foreign trade}

Table A.7 shows the equations for the domestic and foreign trade block. Equations TRD1-TRD3 are related to prices. In TRD1, the export price received by producers, $P E_{c}$, is defined as the world export price, transformed into domestic currency via the exchange rate and adjusted for export taxes and the transactions (trade and transport) cost per unit of exports; the unit transactions cost is defined as the product of an input coefficient $\left(i c e_{c, c^{\prime}}\right)$ and the input price, summed over all inputs. In analogous fashion, equation TRD2 defines the domestic currency import price for demanders, $P M_{C}$, on the basis of the world import price, the exchange rate, and import tariffs, in this case with the unit transactions cost added to the price; note that this price does not, include the sales tax (cf. equation TRD7).In both equations, it is assumed that the modeled economy is small; thus, world prices for exports and imports $\left(p w e_{c}\right.$ and $\left.p w m_{c}\right)$ are exogenous. Equation TRD3 links the demander and supplier prices for domestic output sold domestically, $P D D_{c}$ and $P D S_{c}$ : the demander price is defined as the supplier price plus the transactions cost per unit of domestically sold output; as will be discussed below, either of these prices can be seen as the market-clearing price for this category of outputs (cf. equation SYS2).

Equations TRD4-TRD7 explain the allocation of domestic demands between imports and domestic purchases and define the related demander price of composite commodities, made up of imported and/or domestically produced commodities. Following the Armington assumption, we assume that products are differentiated on the basis of their origin (domestic or foreign). Consequently, it is possible to account for two-way trade (i.e., the same product may be exported and imported simultaneously; this is in distinction to merely accounting for net trade). The composite commodities that are demanded domestically are a CES aggregation of domestic and imported products (equation TRD4). For commodities that lack either imports or domestic production, TRD4 is replaced by TRD5: their composite quantities are simply identical to the quantity of imports or 
the quantity of domestic sales of domestic output. ${ }^{33}$ For commodities with both imports and domestic purchases of domestic output equation TRD6 is the tangency condition that determines the domestic/imported mix; it is part of the first-order conditions for demander cost minimization. Equation TRD7 implicitly defines the price of the composite product, $P Q_{c}$, given the composite quantity, $Q Q_{c}$, and the sum of the values of imports and domestic purchases, adjusted upward for the sales tax; notice that the tax base excludes the tax.

Equations TRD8-TRD11 turn to the supply side, addressing the allocation of domestic output between two destinations: exports and domestic markets: output is viewed as imperfectly transformable between these two destinations. A CET (Constant Elasticity of Transformation) function defines the allocation of output, $Q X_{c}$, between exports and domestic sales $\left(Q X_{c}\right.$ and $Q D_{c}$; equation TRD8). ${ }^{34}$ For products that lack exports or domestic sales, equation TRD8 is replaced by equation TRD9: output quantity equals the export quantity or the domestic sales quantity. Equation TRD10 defines the ratio between exports and domestic sales for commodities that have both; it is part of the first-order conditions for producer profit maximization. Equation TRD11 implicitly defines the producer price for commodity $c, P X_{c}$, given the output quantity and, on the right-hand side, the sum of the values of domestic sales and exports at producer prices.

The last equation in this block, TRD12, defines the total transactions demand, i.e., the demand for commodities (in practice trade and transportation services) that are used in the distribution of commodities between (1) producers and the border (for exports); (2) producers and domestic demanders (for domestic sales); and (3) demanders and the border (for imports). For each category, the transactions demand is defined as the quantity that is distributed (exported, imported, or sold domestically) multiplied by exogenous unit input coefficients.

Table A.8. Equations for domestic institutions.

\begin{tabular}{c|c|c|l}
\hline INS1 & $Y I F_{i, f}=\operatorname{shif}_{i, f} \cdot Y F_{f}\left(1-t f_{f}\right)$ & $\begin{array}{c}i \in I N S \\
f \in F\end{array}$ & $\begin{array}{l}\text { Institution } \\
\text { al factor } \\
\text { income }\end{array}$ \\
\hline INS2 & $Y I_{i}=\sum_{f} Y I F_{i, f}+\operatorname{trnfr}_{i, g o v} \cdot \overline{C P I}+t r n s f r_{i, \text { row }} \cdot E X R$ & $\begin{array}{l}\text { Non-gov't } \\
\text { institution } \\
\text { income }\end{array}$ \\
\hline INS3 & $+\sum_{i^{\prime} \in I N S D N G} T R I I_{i, i^{\prime}}$ & $i \in I N S D S_{i}=m p S b_{i} \cdot M P S S C A L$ & $\begin{array}{l}\text { Marginal } \\
\text { propensity } \\
\text { to save }\end{array}$ \\
\hline
\end{tabular}

33 The elasticity of substitution between domestic purchases and imports is $\sigma_{c}^{q}=$ $1 /\left(1+\rho_{c}^{q}\right)$.

${ }^{34}$ The elasticity of transformation between domestic sales and exports is $\sigma_{c}^{x}=1 /\left(\rho_{c}^{x}-1\right)$. 


\begin{tabular}{|c|c|c|c|}
\hline INS4 & $\operatorname{SAVINS}_{i}=M P S_{i}\left(1-T Y_{i}\right) Y I_{i}$ & $i \in I N S D N G$ & $\begin{array}{l}\text { Non-gov't } \\
\text { institution } \\
\text { savings }\end{array}$ \\
\hline INS5 & $T R I I_{i, i^{\prime}}=\operatorname{shii}_{i, i^{\prime}}\left(1-M P S_{i^{\prime}}\right)\left(1-T Y_{i^{\prime}}\right) Y I_{i^{\prime}}$ & $\begin{array}{l}i \in I N S \\
i^{\prime} \in I N S D N G\end{array}$ & $\begin{array}{l}\text { Institu- } \\
\text { tional } \\
\text { transfers }\end{array}$ \\
\hline INS6 & $E H_{h}=\left(1-\sum_{i \in I N S} s h i i_{i, h}\right)\left(1-M P S_{h}\right)\left(1-T Y_{h}\right) Y I_{h}$ & $h \in H$ & $\begin{array}{l}\text { Household } \\
\text { consump- } \\
\text { tion expen- } \\
\text { diture }\end{array}$ \\
\hline INS7 & $Q H_{c, h}=\gamma_{c, h}+\frac{\beta_{c, h}}{P Q_{c}}\left(E H_{h}-\sum_{c^{\prime}} P Q_{c^{\prime}} \cdot \gamma_{c^{\prime}, h}\right)$ & $\begin{array}{l}c \in C \\
h \in H\end{array}$ & $\begin{array}{l}\text { Household } \\
\text { consump- } \\
\text { tion } \\
\text { demand } \\
\end{array}$ \\
\hline INS8 & $\begin{aligned} & Y G=\sum_{i \in I N S D N G} T Y_{i} \cdot Y I_{i}+\sum_{f \in F} t f_{f} \cdot Y F_{f} \\
&+\sum_{c \in C} t q_{c}\left(P M_{c} \cdot Q M_{c}+P D D_{c} \cdot Q D_{c}\right) \\
&+\sum_{c \in C} t m_{c} \cdot E X R \cdot p w m_{c} \cdot Q M_{c}+\sum_{c \in C} t e_{c} \\
& \cdot E X R \cdot p w e_{c} \cdot Q E_{c}+\sum_{a \in A} t a_{a} \cdot P A_{a} \cdot Q A_{a} \\
&+E X R \cdot \text { trnsfr }_{\text {gov }, \text { row }}+\sum_{i \in I N S D N G} T R I I_{\text {gov }, i} \\
&+\sum_{f \in F} Y I F_{\text {gov }, f}\end{aligned}$ & & $\begin{array}{l}\text { Govern- } \\
\text { ment } \\
\text { income }\end{array}$ \\
\hline INS9 & $T Y_{i}=t y b_{i} \cdot T Y S C A L$ & $i \in I N S D N G$ & $\begin{array}{l}\text { Direct tax } \\
\text { rate }\end{array}$ \\
\hline INS10 & $Q G_{c}=q g b_{c} \cdot \overline{Q G S C A L}$ & $c \in C$ & $\begin{array}{l}\text { Govern- } \\
\text { ment } \\
\text { consump- } \\
\text { tion } \\
\text { demand } \\
\end{array}$ \\
\hline INS11 & $\begin{array}{c}E G=\sum_{c \in C} P Q_{c} \cdot Q G_{c}+\sum_{\substack{i \in I N S D N G\\
}} t_{t r n s f f r_{i, g o v}} \cdot \overline{C P I} \\
\text { trnsfrow }, \text { gov } \\
\cdot E X R\end{array}$ & & $\begin{array}{l}\text { Govern- } \\
\text { ment } \\
\text { expend- } \\
\text { iture }\end{array}$ \\
\hline INS12 & $S A V G=Y G-E G$ & & $\begin{array}{l}\text { Govern- } \\
\text { ment } \\
\text { savings }\end{array}$ \\
\hline INS13 & $\overline{R S A V G}=\frac{S A V G}{\overline{C P I}}$ & & $\begin{array}{l}\text { Real } \\
\text { govern- } \\
\text { ment } \\
\text { savings }\end{array}$ \\
\hline
\end{tabular}




\section{Domestic institutions}

The equations presented in Table A.8 define current incomes and their uses (consumption, savings, and transfers) for domestic institutions (government and non-government). The first equation, INS1, computes the factor income received by each institution $\mathrm{i}$ as the total income of the factor $\left(Y F_{f}\right)$ net of direct taxes on factor income multiplied the share of the institution in the total endowment of the factor $\left(\operatorname{shif}_{i, f}\right)$.

Equations INS2-INS7 apply to domestic non-government institutions (in the set INSDNG), invariably one or more households but, depending on the database, potentially also including enterprises and other institutions like NGOs. This set of equations defines their incomes, savings, and spending. As shown by equation INS2, the income of institution $i$ is the sum of four elements: (1) factor income; (2) transfers from the government, indexed to the consumer price index (CPI); (3) transfers from rest of the world (i.e., remittances), exogenous in foreign currency and transformed into domestic currency; and (4) transfers from other domestic non-government institutions. Equation INS3 computes the marginal propensity to save as the exogenous base rate, $m p s b_{i}$, multiplied by a scaling factor, MPSSCAL, which here is endogenous; for the base solution, the scaling factor is equal to one but otherwise it may take on other values and, under alternative treatments of the savings-investment balance, it may be exogenous. Equation INS4 computes the value of savings for each institution as its total income net of direct taxes multiplied by its savings rate. Equation INS5 defines transfers from domestic nongovernment institutions to any other institution (government, non-government, or the rest of the world). These transfer flows are endogenous, defined as exogenous shares of the incomes of domestic non-government institutions net of direct taxes and savings. Equation INS6 computes the consumption spending by domestic non-government institutions as their income net of transfers to other institutions, savings, and direct taxes.35 Equation INS7 defines consumption expenditure for the subset of consuming units in INSDNG, labeled as households - INSDNG may also include institutions that do not consume, like enterprises. Household consumption expenditure is distributed across commodities on the basis of a Stone-Geary utility function from which linear expenditure system (LES) demand functions are derived.

A parallel set of equations, INS8-INS13, defines incomes, savings, and current spending for the government. Equation INS8 computes government current income as the sum of (1) revenues from direct taxes (on institutions and factors);

${ }^{35}$ Among the potential domestic non-government institutions, enterprises do not consume by definition whereas households consume. If the database includes NPISHs (non-profit institutions in the service of households, including NGOs), then these may also consume. 
(2) revenues from indirect taxes (taxes on sales, imports, exports, imports, and producer output value); (3) transfers from the rest of the world and domestic nongovernment institutions; and (4) factor income. Note that transfers from the rest of the world to the government, like private transfers, are exogenous in foreign currency and transformed into domestic currency. As indicated by Equation INS9, initial direct tax rates are scaled by the variable TYSCAL, the variable that clears the current government budget. Equation INS10 computes government consumption of $c$ as the product of (a) $q g b_{c}$, which is exogenous and initially holds the base-year quantities; and (b) a scaling factor, QGSCAL, which here also is exogenous; for the base solution, this scaling factor is equal to one but otherwise it may take on other values and, under alternative treatments of the government budgetary balance, it may be endogenous. Government current spending (equation INS11) is defined as the sum of government consumption and government transfers (domestic and/or to the rest of the world). Nominal government savings is the difference between current income and current spending (equation INS12). Real government savings, the ratio between nominal government savings and the CPI (the numéraire), is fixed (equation INS13). ${ }^{36}$

Table A.9. Equations for system constraint and price indices.

\begin{tabular}{|c|c|c|c|}
\hline SYS1 & $\begin{aligned} \sum_{c \in C} p w e_{c} \cdot Q E_{c}+ & \sum_{i \in I N S D} t r n s f r_{i, r o w}+\sum_{f \in F} t r n s f r_{f, r o w} \\
& +\overline{S A V F} \\
& =\sum_{c \in C} p w m_{c} \cdot Q M_{c}+t_{\text {trnsfr }} r_{\text {row }, \text { gov }} \\
& +\sum_{i \in I N S D N G} \frac{T R I I_{\text {row }, i}}{E X R}+\sum_{f \in F} \frac{Y I F_{\text {row }, f}}{E X R}\end{aligned}$ & & $\begin{array}{l}\text { Current account } \\
\text { of the balance } \\
\text { of payments }\end{array}$ \\
\hline SYS2 & $\begin{array}{c}\sum_{h} Q H_{c, h}+\sum_{a} Q I N T_{c, a}+Q I N V_{c}+Q G_{c}+q d s t k_{c}+Q T_{c} \\
=Q Q_{c}\end{array}$ & $c \in C$ & $\begin{array}{l}\text { Composite } \\
\text { commodity } \\
\text { demand-supply } \\
\text { balance }\end{array}$ \\
\hline SYS3 & $Q I N V_{c}=q i n v b_{c} \cdot \overline{Q I N V S C A L}$ & $c \in C$ & $\begin{array}{l}\text { Investment } \\
\text { demand }\end{array}$ \\
\hline
\end{tabular}

36 The model would not be homogeneous (of degree zero) if $S A V G$ were fixed; hence the need to introduce real government savings. Note that, for domestic non-government institutions, savings is expressed as a share of income net of direct taxes. By construction, their income is equal to the sum of their spending (consumption, savings, direct tax payments and transfers to other institutions). For the government, income and current spending are specified independently with savings as the difference. Other government closures are possible; for example, fixing TYSCAL and flexing RSAVG would turn government savings into the clearing variable for the government. 


\begin{tabular}{l|c|l}
\hline SYS4 & $\sum_{i \in I N S D N G} S A V I N S_{i}+S A V G+E X R \cdot \overline{S A V F}$ & $\begin{array}{l}\text { Savings- } \\
\text { investment } \\
\text { balance }\end{array}$ \\
\hline SYS5 & $=\sum_{c \in C} P Q_{c}\left(Q I N V_{c}+q d s t k_{c}\right)+W A L R A S$ & $\begin{array}{l}\text { Consumer price } \\
\text { index }\end{array}$ \\
\hline SYS6 & $\sum_{c \in C} P Q_{c} \cdot c w t s_{c}=\overline{C P I}$ & $\begin{array}{l}\text { Producer price } \\
\text { index }\end{array}$ \\
\hline
\end{tabular}

System constraints and price indices

The last equation block, presented in Table A.9, defines system constraints (the current account of the balance of payments, commodity markets, and the savingsinvestment balance) and two aggregate price indices (the $C P I$ and the producer price index for domestic sales), either of which may be the numéraire of the model. The constraints for factor markets were defined in the first equation block.

The rest of the world is represented by the current account of the balance of payments, expressed in foreign currency (equation SYS1). Except for the exchange rate, $E X R$, which is used to convert terms in domestic currency into foreign currency, the different terms in this balance were covered in the preceding blocks. The left-hand side shows the inflows of foreign exchange: it is the sum of exports, current transfers, factor payments, and foreign savings; the latter is an item that corresponds to the current-account deficit and has as its counterpart a surplus in the capital and financial account. On the right-hand side, foreign exchange outflows out due to imports, current transfers from the government and nongovernment institutions, and factor payments. It is assumed that foreign savings are exogenous and that external balance is achieved via adjustments in the value of EXR. To illustrate, elimination of a balance of payments deficit would be achieved via depreciation (a higher value for $E X R$ ), which adjusts the real exchange rate, raising the $P E_{c} / P D S_{c}$ ratios for suppliers and reducing the $P D D_{c} / P M_{c}$ ratios for demanders, in this way bringing about higher exports and lower imports (cf. equations TRD1, TRD2, TRD6 and TRD10); through the same mechanisms, appreciation would eliminate a surplus. Alternatively, the exchange rate could be fixed (implicitly indexed to the model numéraire; see discussion below); if so, adjustment in foreign savings would clear the external balance.

Equation SYS2 is the condition for supply-demand equilibrium in commodity markets. The composite supply, made up of domestic and imported varieties, is used for household consumption, intermediate use, investment, government consumption, and changes in inventories. For the domestic component of the commodity market (where quantities demanded for and supplied of domestic output meet - the variable $Q D_{c}$ in equations TRD6 and TRD10, respectively), demanders respond to changes in $P D D_{c}$ and suppliers to changes in $P D S_{c}$, two 
variables that are linked (equation TRD3). To illustrate, if this market has excess demand for a commodity $c$, an increase in $P D S_{c}$ would increase quantities supplied (by generating incentives for higher production of $c$ and allocation of a larger share of this output to domestic sales as opposed to exports), while the simultaneous increase in $P D D_{c}$ would reduce quantities demanded. As stated above, the smallcountry assumption applies to the imported part of the commodity market: the quantities supplied are infinitely elastic at exogenous international prices and could be viewed as clearing this commodity market constraint.

The only term in equation SYS2 that had not yet been covered, investment demand (by origin), $Q I N V_{c}$, is defined in equation SYS3, which computes investment demand for $c$ as the product of (a) qinvb $b_{c}$, which is exogenous and initially holds the base-year quantities; and (b) a scaling factor, QINVSCAL. Like QGSCAL, QINVSCAL is exogenous and equal to one for the base solution. In other simulations it may take on other values and, depending on the treatment of the savings-investment balance, the next equation, it may be endogenous.

In the savings-investment balance, SYS4, the left-hand side defines available savings as the sum of savings from domestic non-government institutions, the government, and the rest of the world; the right-hand side defines the total investment value. ${ }^{37}$ The variable WALRAS must be zero in equilibrium (if not, savings and investment are not equal and the model did not solve correctly). In our application, this balance is cleared by adjustments in the variable MPSSCAL, which is endogenous (see equation INS4). In order to switch from savings-driven investment to investment-driven savings, the analyst may exogenize MPSSCAL and endogenize QINVSCAL (in equation SYS3). Finally, equation SYS5 defines the $C P I$, which is exogenous and the model numéraire, as a weighted average of composite commodity prices $\left(P Q_{c}\right)$; the weights are the shares of each commodity in private (i.e., household) consumption. ${ }^{38}$

\footnotetext{
${ }^{37}$ Given that the model is static, there is no need to disaggregate investment into different types (for example government and non-government) or to address how different types of investment are financed.

${ }^{38}$ Under alternative closures for the balance of payments, the analyst may wish to fix the real exchange rate, which typically is defined as the ratio between the nominal exchange rate and an index of domestic producer prices; if so, it would be necessary to augment the model with this variable and an equation in which it is defined.
} 